\title{
برنامج قائم على النمذجة الحرفية فى علاج صعوبات الكتابة لدى تلاميذ المرحلة الابتدائية
}

\section{3و}

هدف البحث إلى علاج صعوبات الكتابة لدى تلاميذ العرحلة الابتدائية من خلا إعداد برنامج قائم

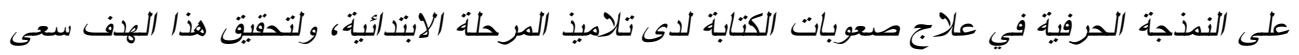

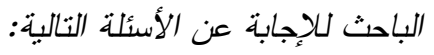

$$
\text { ' ـ ما أهم الصعوبات التي تواجه تلاميذ الصف الثاني الابتدائي في تعلم الكتابة؟ }
$$

r _ ما البرنامج العلاجى القائم على الندذجة الحرفية في علاج صعوبات الكتابة لدى تلاميذ المرحلـــــا

الابتدائية؛

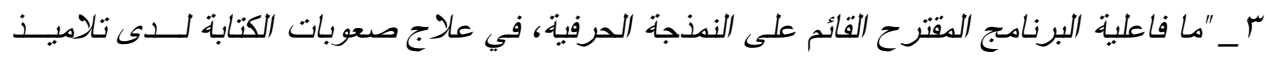

$$
\text { الصف الثاني الابتدائي؟ }
$$

وتكونت عينة البحث من (T) تلميذ من تلاميذ الصف الثاني الابتدائي قسمت إلــى مجدـوعتين

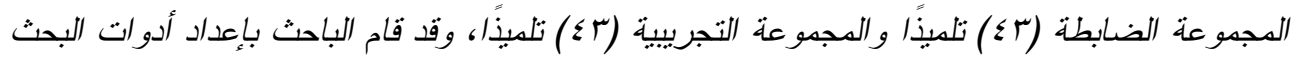

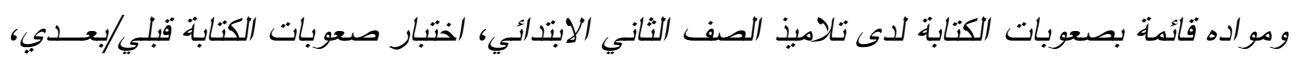

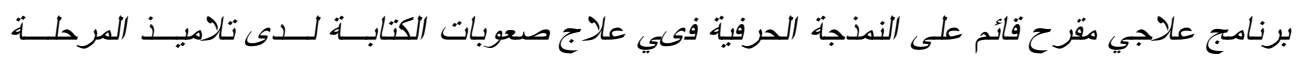
الابتدائية.

$$
\text { وقد أثشارت نتائسج البحث إلى: }
$$

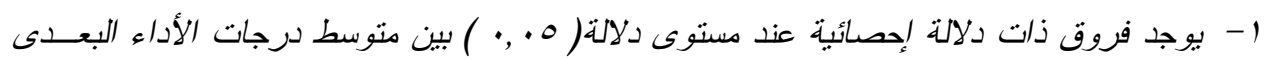

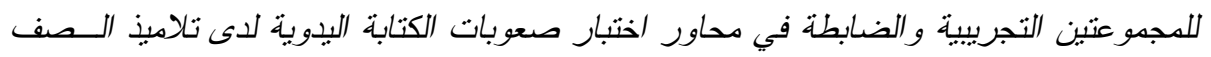

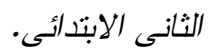

r- بوجد أثر دال إحصائيا للبرنامج الحالي في علاج صعوبات الكتابة لدى تلاميـــ الـصف الثــاني 


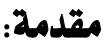

وظهرت صعوبات التعلم متلازمة مع حالات

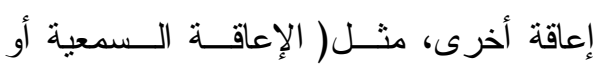

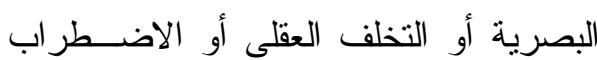

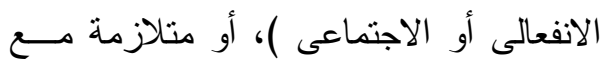
مؤثرات بيئة أخرى ( كالاختلافات التقافية أو الو لون طرق التدريس غير المناسبة) فإن صعوبات الــتعلم لا تكـــون نتيجــة مباثثــرة لتــأثنير هذه الإعاقات، أو لهـــه المــؤثرات غيــر

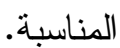

\section{وتنقسم هذه الصعوبات إلى ما يلى:} 1- ـعوبات نمائية وتتضمن:

أــ ـ صعوبات التعلم الأوليــة وتــشمل:

(الانتباه، و الذاكرة، و الإدر الك)

ب- صعوبات التعلم الثانوية وتــشمل:

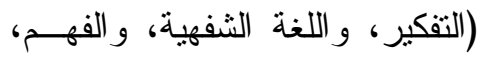

$$
\text { و الكلام) }
$$

r- صعوبات التعلم الأكاديمية، وتـشمل:

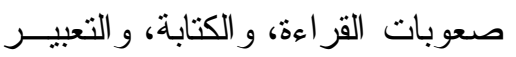

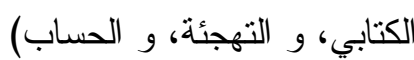

وتختلف التقــدير ات لحجــم مـشكلة صعوبات التعلم، باختلاف البلدان التي تدرس

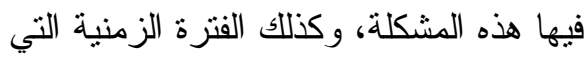
تصدر فيها هذه الدراسات، و الكثافة الــصفية

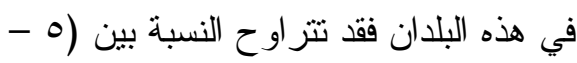
1\%) أو تزيد، لكي تصل إلى (•r\%) من
إن لغتتا العربية ركــن ثابــت مـنـ

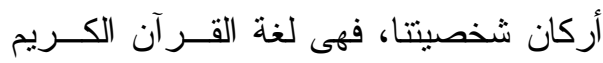
الذى جاء معجزًا فى أسلوبه وبلاغته، فيحق لئه لنا أن نفتخر ونعتز بها، ويجب علينا أن نذود

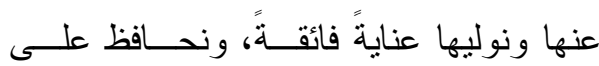

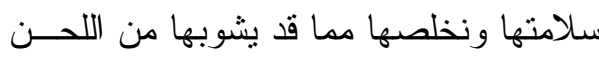

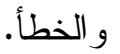

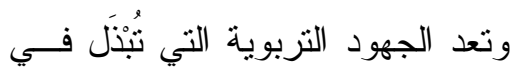

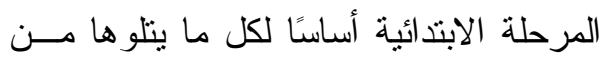

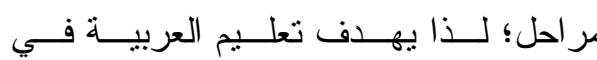
هذه المرحلــة إلــى تمكـين الطفـلـل مــن

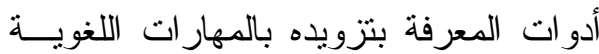

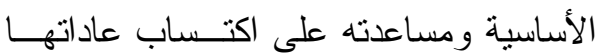
الصحيحة، و إكساب التلاميذ بصفة خاصــة مهار ات القر اءة و الكتابة، فهما أساسا تحقيق

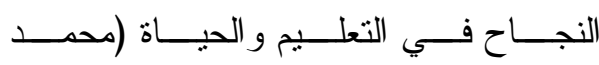

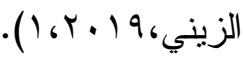
و التلاميذ الذين يعانون من صـــوبات

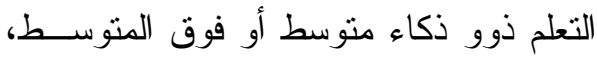
و أحيانًا ما يقعون فى المدى ذئ السوى أو العادى من حيث الذكاء، بل قد يكونون فائقين عقلياً،

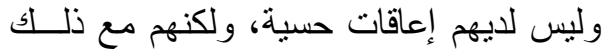
يجدون صعوبة فى تعلم القـــر اءة و الكتابـــة

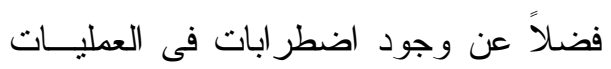
العقلية المتمثلة فى: الانتباه و الإدر الك وتكوين المفهوم و التذكر وحل المشكلة.( و إذا حـدث 
الصعوبات حسب المعايير السابقة ووضــع

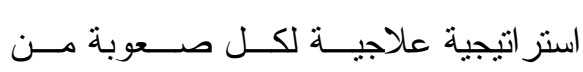

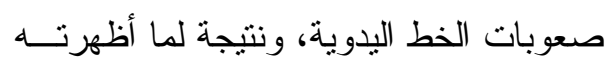
الدر اسات من شيو ع نسبة لا يستهان بها من

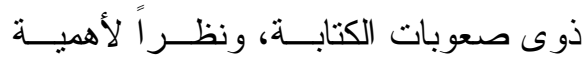
موضوع صعوبات الكتابة كأحد صـــوبات

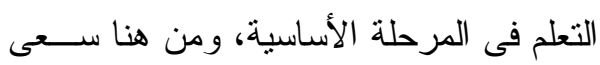
البحث الحالى لإعداد برنامج للحد من تفــاقم

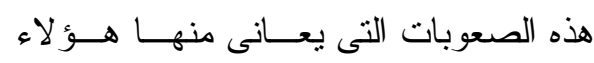

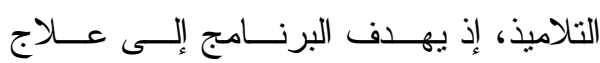
صعوبات الكتابة من خلال النمذجة الحرفيــة

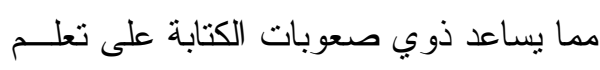

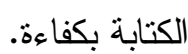
و المتأمل لمعدلات انتشار صــعوبات

الكتابة يستشعر خطورة هذه المشكلة؛ لأنهـــا

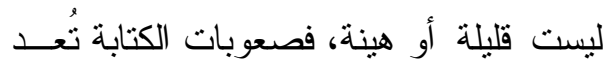
مشكلة كبرى للتلاميذ، وخاصة مع انتقــالهم

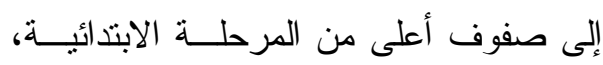

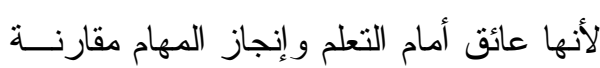
بيقية التلاميذ في نفس العمر . مشكلة البحث :

ويمكن تحديد مشكلة البحث فيما يلي: تحددت مشكلة البحـــث فــى وجــود صعوبات كتابية لدى تلاميذ الــصف النـانى الابتدائى، مما يظهر الحاجة إلــى برنــامج

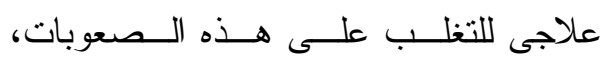

مجمل تلاميذ المدارس.( ), (Smith 2002) Silver \& Hagin, 2002 William Phillips, 2012

و نتشير الدراسات التى أجريت

فى مصر على وجه الخصوص إلى أن نسبة

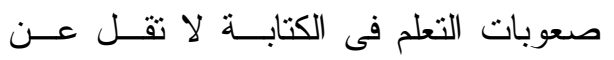

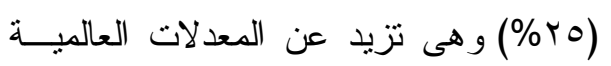

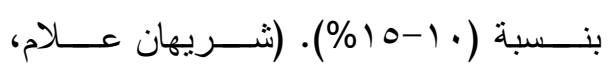

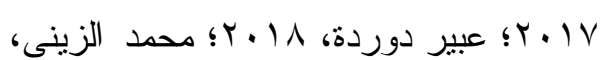
$\cdot(r \cdot 19$

ويعد البرنامج القائم علـــى النمذجـــة

الحرفية، من الأساليب الحديثة في التعلم، إذا

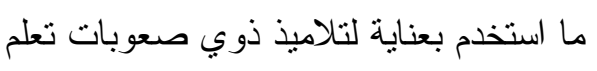

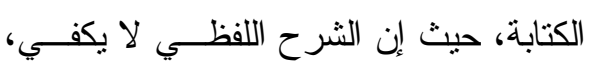

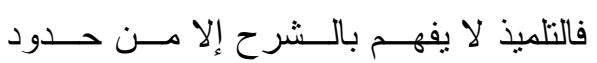

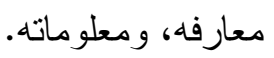

وهذا ما حاول الباحث الانطلاق منـــهـ

في إعداده لبرنامج البحثى( البرنــامج القـائم

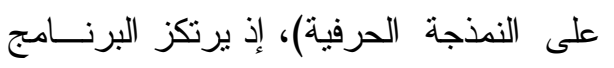

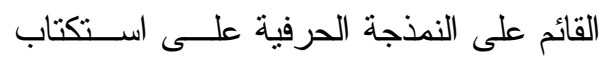
التلاميذ ذوى صعوبات تعلم الكتابة، ثم تحليل

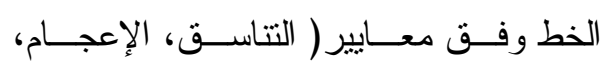
الوضوح، و التو ازن..........إخخ)، ثم تصنيفه وفقا للعيوب الخطية التى تشير إلى صعوبات

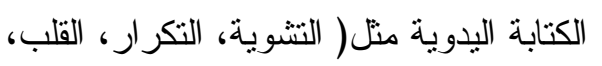

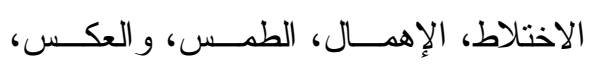

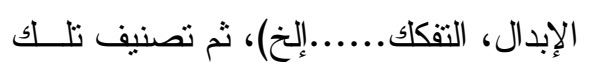




$$
\begin{aligned}
& \text { وتساعدهم فى مواصلة السلم التعليمى } \\
& \text { بنجاح. } \\
& \text { r. الإفادة من النتائج ومـــا تقدمــهـ مــن }
\end{aligned}
$$

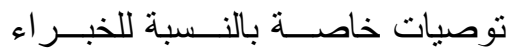

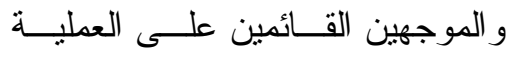

$$
\begin{aligned}
& \text { التعليمية و المهتمين بمجال صـــوبات } \\
& \text { التعلم وخاصة صعوبات الكتابة لكيفية } \\
& \text { تفعيل البرنامج. } \\
& \text { ع. فتح باب إجر اء بحوث ودر اسات ذات } \\
& \text { علاقة بمتغير ات البحث. }
\end{aligned}
$$

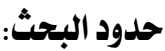

$$
\begin{aligned}
& \text { اقتصر البحث على صعوبات الكتابــة } \\
& \text { اليدوية لاى عينة من تلاميذ الصف التــانى }
\end{aligned}
$$

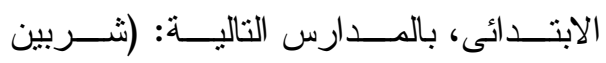

$$
\begin{aligned}
& \text { المشتركة، شمس الدين، المنيلاوي الخاصة، بالهاب }
\end{aligned}
$$

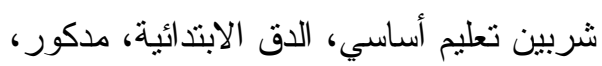

$$
\begin{aligned}
& \text { شهداء شربين، اللوزي القديم)، إدارة شربين }
\end{aligned}
$$

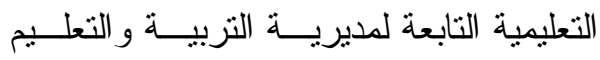

$$
\begin{aligned}
& \text { بالدقهلية بجمهورية مصر العربية. } \\
& \text { أدوات البحث ومو اده: وشملت: } \\
& \text { !. اختبار الذكاء المصور" غير اللفظــى" }
\end{aligned}
$$

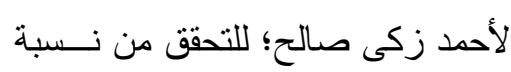

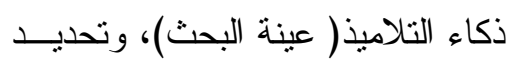

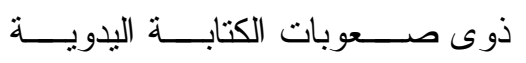

$$
\begin{aligned}
& \text { منهم. }
\end{aligned}
$$

$$
\begin{aligned}
& \text { ولدر اسة هذه المشكلة حاول البحث الحــالى } \\
& \text { الإجابة عن السؤال الرئيس التالى: } \\
& \text { كيف يمكن علاج صعوبات الكتابـة } \\
& \text { لاى تلاميذ المرحلة الابتدائيــة باســتخدام } \\
& \text { برنامج قائم على النمذجة الحرفية؟ } \\
& \text { الصف الثانى الابتدائى? }
\end{aligned}
$$

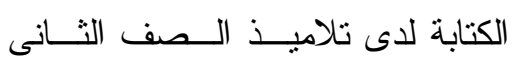

$$
\text { الابتدائى? }
$$

؟ـ. ما فعالية البرنامج المقترح القائم على

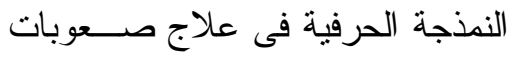

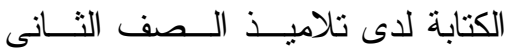

$$
\text { الابتدائى؟ }
$$

يتوقع أن يستقيد من نتائج هذا البحث الفئات

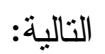

1. معلمو اللغة العربية بمدارس التعلــيم

الابتدائى فى علاج صعوبات القـــر اءة

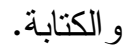

r. ت تلاميذ المرحلة الابتدائية حيث يقـدم

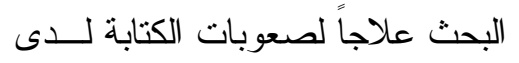

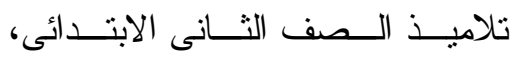




$$
\begin{aligned}
& \text { اختبار صعوبات الكتابة اليدوية لــدى } \\
& \text { تلاميذ الصف الثانى الابتدائى. } \\
& \text { r- ـ يوجد أثـــر دال إحــــائيا للبرنــامج } \\
& \text { الحالي في علاج صــعوبات الكتابـة } \\
& \text { لدى تلاميذ الصف الثاني الابتدائي." }
\end{aligned}
$$

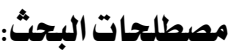

1- البرنامج Program

لغةً: وضع خطة للار اسة وتحــصيل

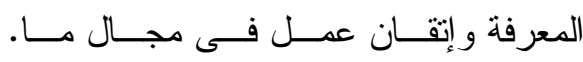

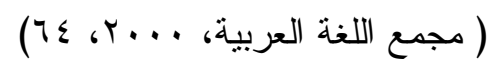

إجرائياً: ويُعرف البرنامج العلاجسى

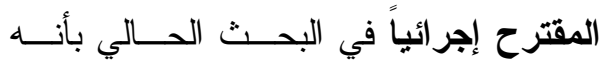

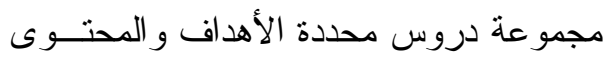
و الوسائل و الأنشطة التعليمية و أساليب التقويم

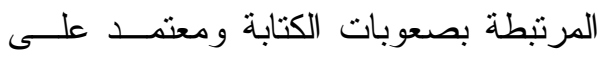

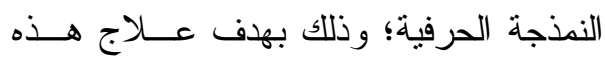

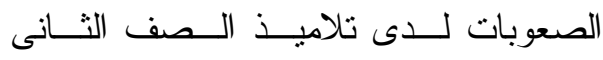
الابتدائى.

r - صعوبات الكتابة Dysgraphia

لغةً: عرفت الصعوبات بأنهـــا جمــع صعوبة، أى: ما اثتلا و عسر • (مجمع اللغة

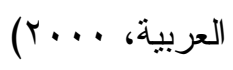

إجر ائيــاً: ويعرفهــــا الباحـــث بأنهــــا

اضطر اب لدى المتعلمين يبدو فى الخلط بين

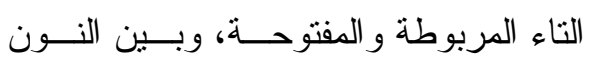

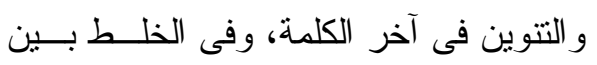

r. مقياس تقدير ســلوك التلميــذ لفـرز

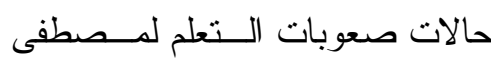

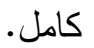

r. اختبار تشخيص صـــوبات الكتابــة

$$
\text { قبلي/ بعدى،( إعداد/الباحث). }
$$

ع. البرنامج القائم على النمذجة الحرفية،

$$
\text { وكتاب التلميذ. }
$$

○. دليل المعلم النظري و العملي.

7. كتاب التلميذ.

$$
\text { منهج البحث: اسُتخدم في البحث: }
$$

المنهج الوصفي: فى إعداد الإطــار

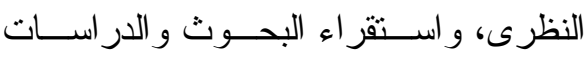

السابقة، وتحديد صعوبات الــتعلم وخاصـــةً

$$
\text { صعوبات الكتابة اليدوية. }
$$

المنهج شبه التجريبي: بهدف در اسة

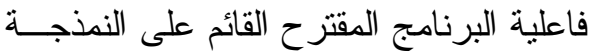
الحرفية المتدرجة فى علاج صعوبات الكتابة لدى تلاميذ الصف الثانى الابتدائى.

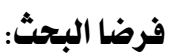

يحاول البحث الحالى اختبار صحة الفـرض

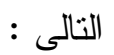

1- يوجد فروق ذات دلالة إحصائية عنـــ

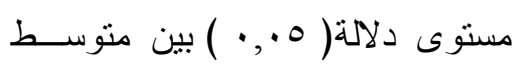

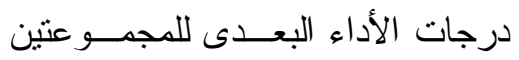

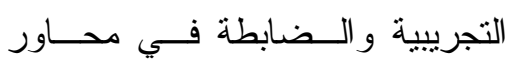


الأساسية للقراءة، و الكتابة، و اجر اء العمليات

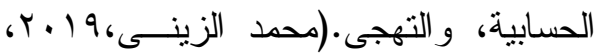

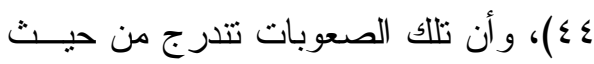

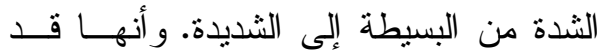
تظهر صعوبات التعلم فى و احدة أو أكثر من العمليــات الفكريــــة كالانتبــــاه، و الـــذاكرة، و الإدر الك، و التفكير وكذلك اللغة الثفوية، و أن مشكلة الكتابة عامـــة و الكتابــــة اليدويـــة خاصة إحدى المشكلات لاى ذوى صعوبات

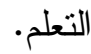
ويمكن تعريف التلاميذ ذوى صعوبات التعلم في هذا البحث بـأنهم مجموعـــة مــن فئن التلاميذ داخــل الفــصل الدر اســـي العــادي يتميزون بنسبة ذكاء تقع في المدى المتوسط أو فوق المتوسط، إلا أنهم يظهرون انخفاضًا دالاً في الأداء الفعلي فــى الكتابــــة البدويــــة الأداء المتوقع منهم في ضوء قدرتهم العقلية العامة بمقدار فرقة در اسية أو أكثر، ويستثىى من هؤلاء التلاميذّ ذوو الإعاقـات الحــسية

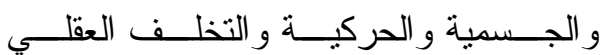

$$
\text { و الاضطر اب الانفعالي. }
$$

هنالك عدة محكات يمكن عن طريقهــا تحديد الأفر اد الذين بعانون من صعوبات في التعلم و هى كالتالي:
الحروف المنشابهة رسماً ونطة ونـاً، وكتابـــة الكلمة بصورة معكوسة، و عدم تمبيز الحرف فى مو اضعه المختلفة من الكلمة ( بــــايتها، وسطها، ونهاينها)، وضع نقاط الحروف فى مون غير أماكنها الصحيحة، وطمـس الحــروف المنقوطة بحيث لا تتميز من غير المنقــوط،

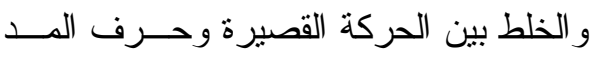
الناتج عن إثباعها.

retteral النمذجــــة الحرفيــــة Modeling

تحليل الخط وفق معــايير ( التتاســق،

الإعجام، الوضوح، و التوازن.........)، ثـــ تصنيفه وفقا للعيوب الخطية التى نشير إلـى صعوبات الكتابة اليدويــــة مثــلـ (التــشوية، التكر ار، القلب، الاختلاط، الإهمال، الطمس، و العكس، الإبدال، التفكك، وصو غها في شكل قو الب أو نماذج يُحتذى بهــــا تتــــوفر فيهــــا المعايير المطلوبة وتخلــو مــن الــصعوبات المحدد في الكتابة يدوياً) الإطار النظري للبحث: المحور الأول: صعوبات الكتابة ا_تعريف ذوي صعوبات التعلم:

ذوى صعوبات التعلم يظهـر لــديهم تتاقضاً حاداً بين التحصيل الدر اسى و القــدرة العقلية فى واحدة أو أكثر من العمليات الآتية

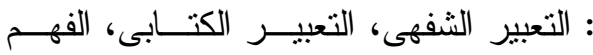
الاستماعى، الفهــم القر ائــى، و المهـــار ات 


\section{r_ مفهوم صعوبة الكتابة الباوية:}

تعد صعوبات الكتابة إحدى صعوبات

التعلم الأكاديمية وهى، تتضمن صعوبات في

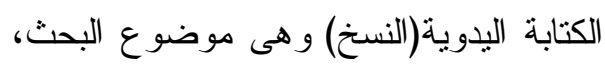
وصعوبات في التهجئة(الإملاء)، وصعوبات موضوع النيات التعبير الكتابي.

و الكتابة اليدوية أو الخط عملية معقدة؛

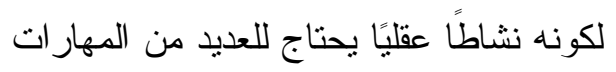
و القدرات، كالدقة في إدر الك الأنماط المختلفة للرموز المرسومة(مهارة بصرية)، ومهـارة

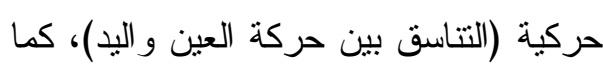

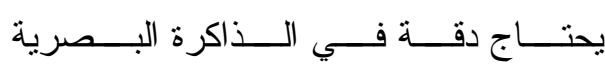
و الحركية.(Deuel, 1995, 56).

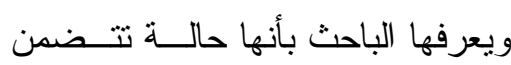

قصوراً فى تتبع رسم الحروف و القدرة على

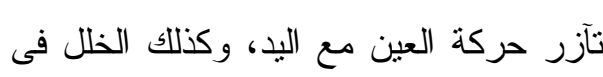

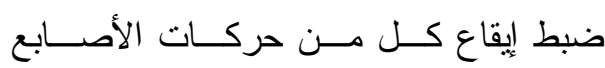

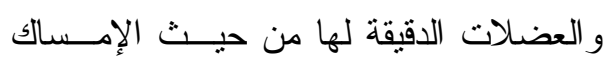

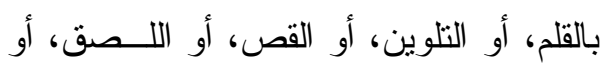

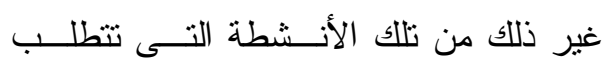

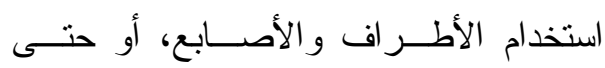
الأنامل، وغالبًا ما ترجع هذه الصعوبات إلى الى الى الصى

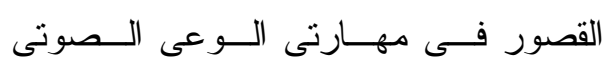
و الإدر الك البصرى، على الرغم مــن عــدم وجود دليل على وجود عجز جسمى أو عقلى أو حسى.
Discrepancy أن التباء

Criterion

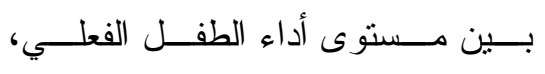

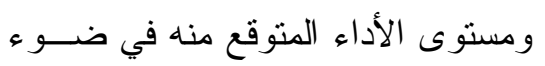
قدرته العقلية العامة. ץ- محك الاستبعادExclusion Criterion،

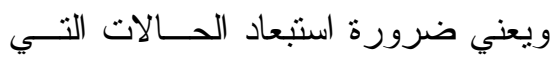

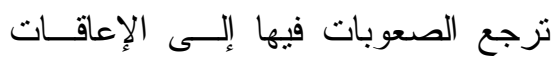

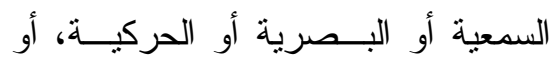

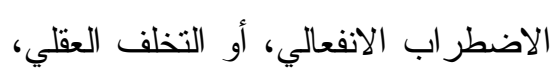

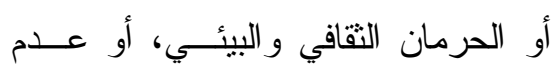
النضج.( سمر هلالي، 10 • Y Y، V؛؛ السعيد

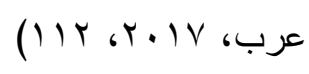

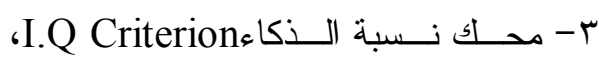
ويعني أن الأطفال ذوي صعوبات التعلم

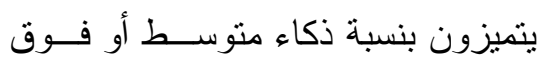
المتوسط. ـ - محكك التربية الخاصـــة: حيــث أوردت بعض التعريفات عدة خصائص تميـز التلاميذ ذوي صعوبات التعلم، منها أنهم لا يستطيعون التعلم بــالطرق العاديــة، دئه

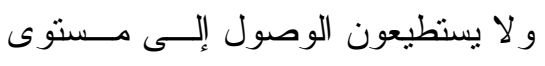

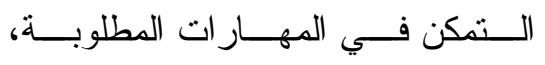

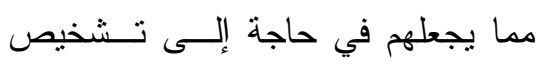
دقيق، وتقديم البرامج العلاجية المناسبة لهم. 
وتثنير الأدبيات في هــذا الـصدد أن

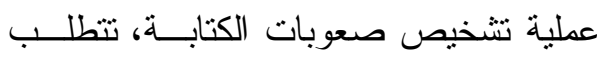
عددًا من الفحوص المتكاملة، منل: الفحوص تُصل الطبية و النفسية و الاجتماعية و التربوية للنلميذ من مني ذي صعوبة التعلم في الكتابة. ولتحديد صعوبة الكتابة يــتم إجــر اء

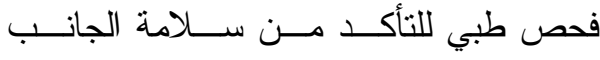
الجسمي، وإجر اء فحص نفسي، كما يوصى

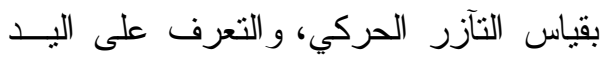
المفضلة في الكتابة، كما ينصح بأخذ نمـاذج ولني

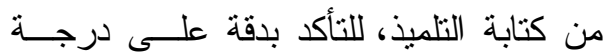

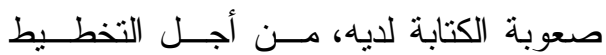
لطريقة علاج أو تعديل صعوبة الكتابة، وهذا

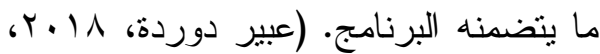

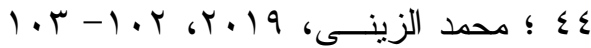

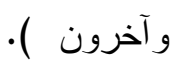
\_ مظــــــــاهر صــــــــوبات الكتابـــــــة:

(Dysgraphia) ويمكن تقسيم مظاهر صعوبات الكتابة إلـى خمسة أقسام: أ. مؤشر ات جسمية. ب. مؤشرات عقلية. ت. مؤشرات انفعالية. ث. مؤشر ات خاصة بالأداء الكتابى. ج. مؤشرات خاصة بالخروج عن أنظمة

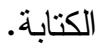

ع_ رداءة الخط اليدوي:

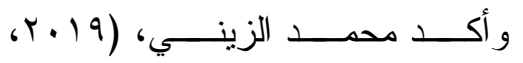

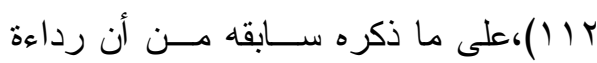

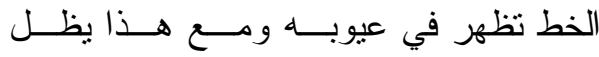
مقروءًا، و البحث الحالي يتفق مع ما بـــكره

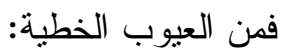
1- بمس المفرغ. r- إهمال المنقوط.

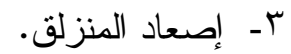
ع - وصل المفصول. 0- - تقريق المجتمع.

ــ تثخيص صعوبات الكتابة اليدوية: كما يتضح أن نشخيص صـــوبات الكتابة يشمل جو انب متعددة، يجب الاهتمــام لتصاي

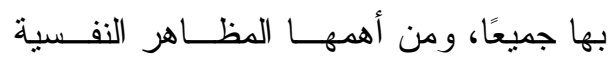

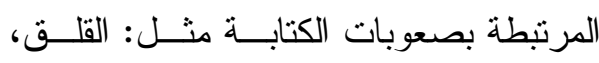

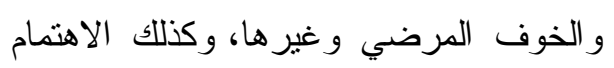

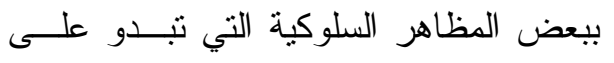
الطفل في أثناء الكتابة؛ كالوضع الخطأ فـي لئي الجلسة، ونوع البد التي يستخدمها، أو طريقة

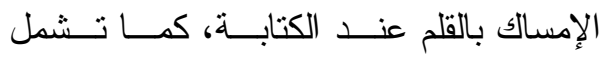

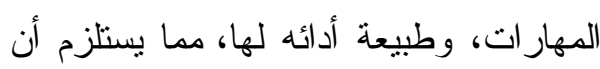

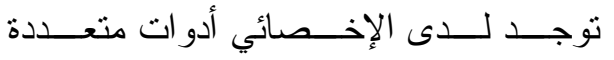

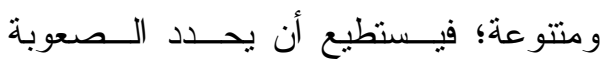
و مظاهر ها و أسبابها بدقة ومن ثم يمكن له أن يضع البرنامج المناسب للعلاج. 


$$
\begin{aligned}
& \text { وفيما يلي تفصيل ما يتعلــق بـالأداء - حذف النقاط أو وضعها فى أماكن غير }
\end{aligned}
$$

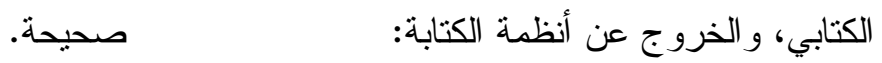

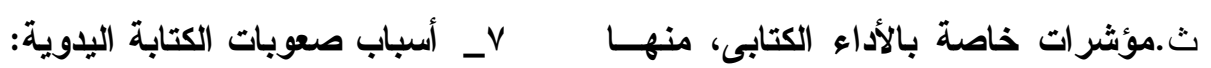

$$
\begin{aligned}
& \text { يمكن تلخيصها في: عوامـلـل تتعلــق }
\end{aligned}
$$

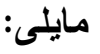

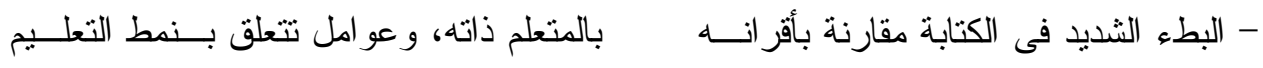

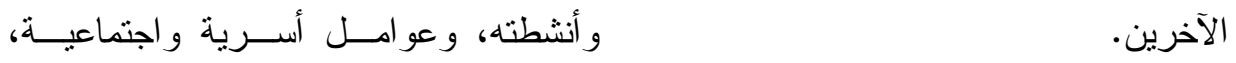

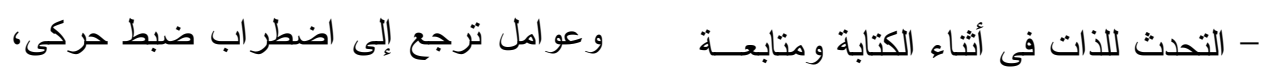

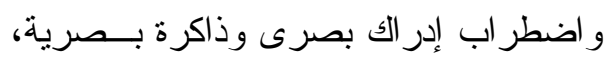

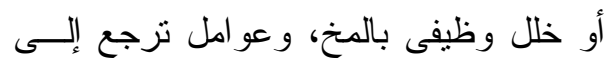

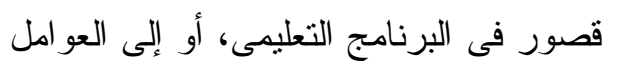

$$
\begin{aligned}
& \text { السابقة كلية ومجملة. } \\
& \text { المحور الثاني: النمذجة الكتابيــة وعـلاج } \\
& \text { صعوبات الكتابة اليدوية. } \\
& \text { لقد تعددت إجراءات وســبل عــلاج }
\end{aligned}
$$

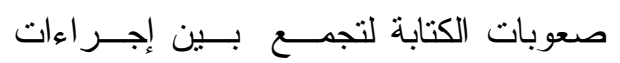

$$
\begin{aligned}
& \text { صحية ونفسية، و إجر اءات نربوية تدريسسية }
\end{aligned}
$$

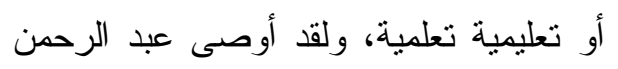

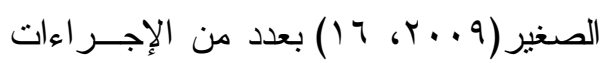

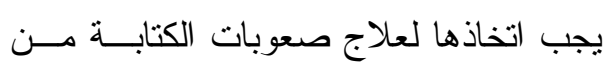

$$
\begin{aligned}
& \text { أهمها: } \\
& \text { أو مشاهدة اليد التى تكتب. } \\
& \text { - سو ء أدو ات الكتابة. } \\
& \text { - صعوبات فى كتابة الخطوط المنحنية أو } \\
& \text { المائلة أو المنكسرة. - مئ. } \\
& \text { ج. مؤشر ات خاصة بالخروج عـن أنظمـة }
\end{aligned}
$$

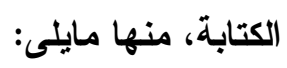

$$
\begin{aligned}
& \text { - افتقار الكتابة إلى الترتيــبـ و التتـسيق } \\
& \text { و التتظيم و عدم التقبد بالسطر . لن. } \\
& \text { - - ضعف الانتظام فى حجم وشكل واتجاه } \\
& \text { الكتابة. } \\
& \text { - يكتب كلمات أو حروف غير منتهية أو }
\end{aligned}
$$

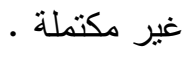

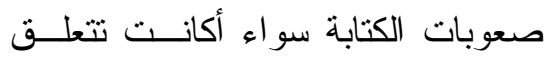

$$
\begin{aligned}
& \text { بالمخ أو البصر أو شئ آخر . } \\
& \text { - عكس الحروف و الأرقام كما لو كانــت } \\
& \text { فى المر آة. } \\
& \text { - الاكثار من الكتابة و المسح دون تتظيف }
\end{aligned}
$$


كاستر اتيجية تعليمية علاجية تعتــــ علـى

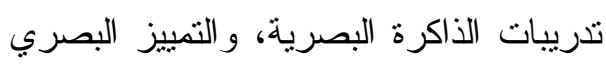

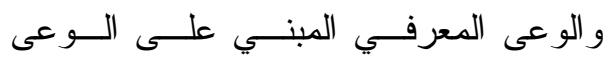
البصري مع التأكيد على أهمية تتمية مهار ات

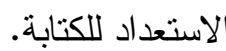

أما سليمان عبد عبد الواحد، (• (. ؟، ع عr) فقد اقترح العلاجات التالية: العلاج الطبى الجسمى:

إذا كان التلميذ يحتــاج إلــى أجهــزة

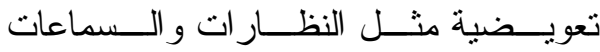
والأطر اف الصناعية، بالإضـافة إلى العــلاج بالعقاقير حسب الحالة المرضية. • العلاج و الإرشاد النفسى:

إذا كان ميل المتعلم للعمل المدرسـى

سلبيًا أو يعانى المتعلم من نشاط زائد. • التوجيه والإرشاد الأسرى:

يتمنل فى توجيه الأسرة وإرشــادها

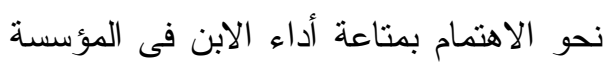

$$
\text { التربوية. }
$$

العلاج التربوى: الذى يتم داخل حجـرة

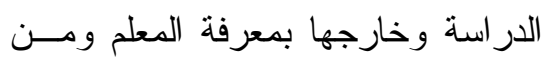

$$
\text { يعاونه ويشتمل: }
$$

$$
\text { - علاج اضطر اب الضبط الحركى. }
$$$$
\text { - تحسين الإدر الك البصرى. }
$$$$
\text { - تحسين الذاكرة البصرية. }
$$

$$
\text { والكتــابى، ومناســبة لنــوع ع الــصعوبة }
$$

- تدريب المتعلمين على نـــاذج حركيــة

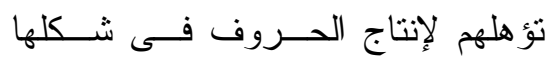

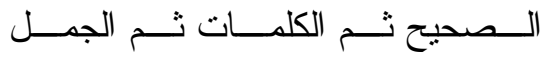

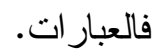
- تدريب الذاكرة البصرية على الحــروف

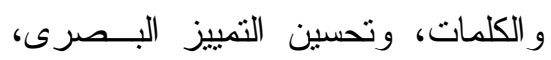
وذلك بو اسطة الأنشطة الكتابية. - تدريب المتعلمين على الوعى المعرفـى ئ بالحروف و الكلمات، و هنا يجــب علــى لـــي

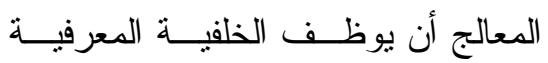
السابقة لاى المتعلمين فى تعلم الكتابـــة

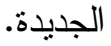
- ضرورة تو الى تقــديم العــلاج لــذـى

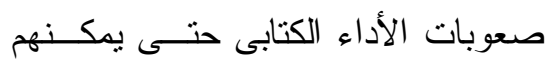
التخلص منها نهائيًا. - تتمية استعداد التلميذ لمهارة الكتابة؛ ويتم

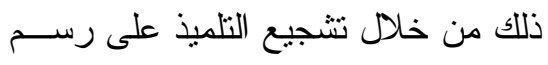

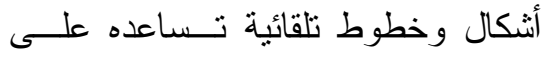
إتقان الكتابة بعد ذلك.( أمين صــبرى، لوهـ

$$
\text { (V) } 6 r \cdot .9
$$

ويتضح مما ســبق أهميــة تــدريب المتعلمين على النماذج الحركية التي تؤهلهم

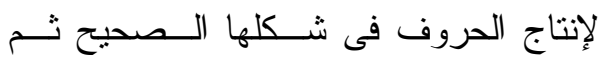

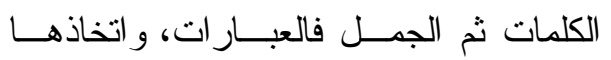


وعلى سبيل المثال يُعرض حرف البــاء

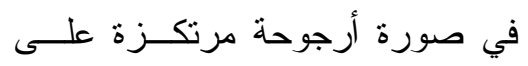
النقطة تحتها، وتعرض الذال في شكل

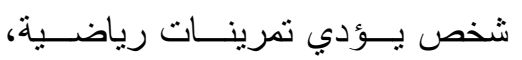
وتعرض الهاء في شكل ورقة تــوت ندون

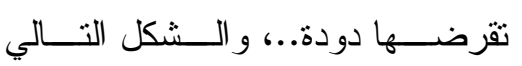
يوضح عرضا رسوميا متحركا لحرف

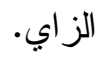

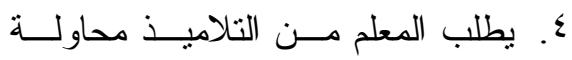

التدرب على كتابتها و اقتفائها يدويا. ○. يُطلَب من التلاميذ تكوين كلمات جديدة

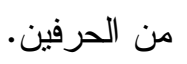
و اتفق معظم الباحثين على أن التعلــيم الو اضح المحدد للكتابة اليدوية سوف يحسـسن من إنتاج التناميذ ليس فقط فى الكتابة اليدوية

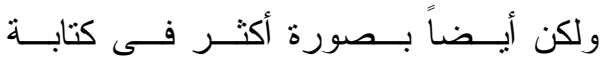

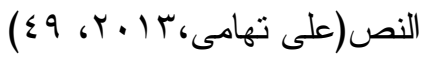

مما سبق يتضح دور النمذجــة فـي علاج صعوبات الكتابة، حيث إن استر اتيجية

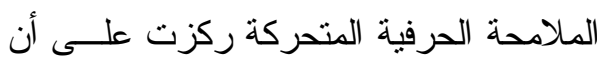

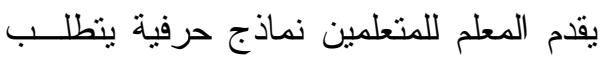

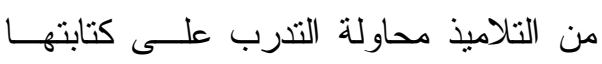

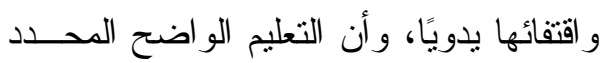

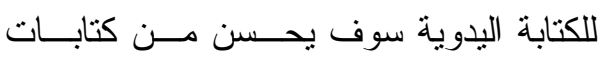

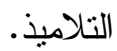

$$
\text { - عــلاج صـــعوبات تـشكيل الحـروف }
$$

- السر عة و التصويب فى كتابة المتعلم. مما سبق يتضح أن علاج صــعوبات الكتابة يتطلب جوانب أساسية تعــــ تمهيــدًا

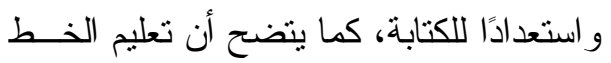

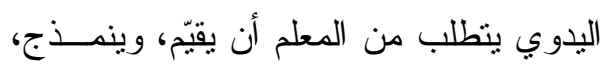

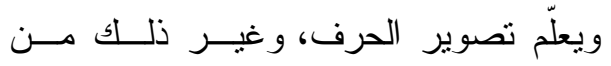

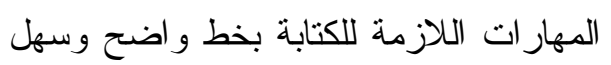

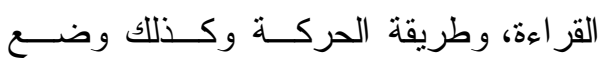
الجسم، ومسكة القلم، ووضع الورقة في أثناء ولقد قدّم محمد الزينى (1 . . r، 9 (1-

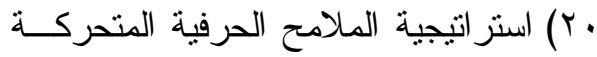
لعلاج صعوبات الكتابة اليدوية، وهى تـسير في خطوات تتضمن كل خطوة عــددًا مــن الإجر اءات يمكن بيانها فيما يلي:

1. يُعرض حرفان متشابهان رسما علـى لئى

التلاميذ مصحوبين بصوتيهما الــدالين

$$
\text { عليهما. }
$$

r. بدرب التلاميذ على التمييز بينها مــن

خلا الفارق في عدد النقاط أو شـــكل لائل

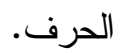

r. يُعرض كل حرف في تصور رسومي

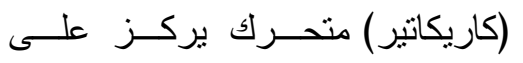

ملامحها (أجز ائها) التي تتكون منها. 
ع- مدخل الرموز البصرية والأكرة:

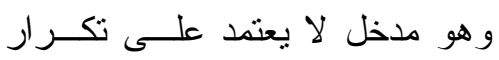

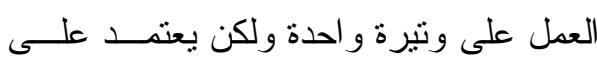

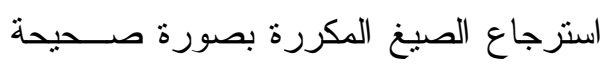

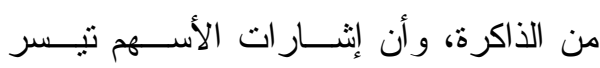

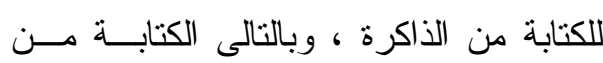

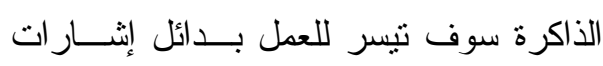
الأسهم. •ـ - مدخل النسخ: وفيه يفحص الأطفال شكل الحــرف،

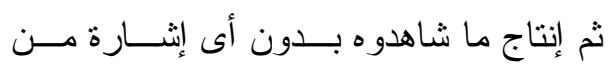
المعلم تتعلق بكل الحــرف أو اســترجاعه. ويستخدم هذا المدخل عملياً فــى الممارســـة لئسة

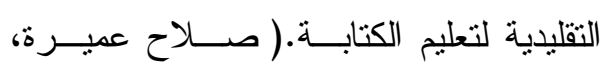

$$
\text { (r...r }
$$

ويرى الباحث أنه مــن الممكـن أن

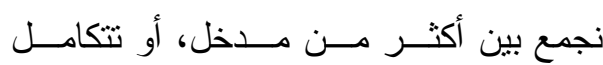

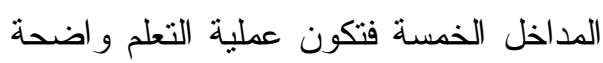
جلية بقيادة المعلم. إجرايات البحث:

تم اتباع الإجراعات التالية للإجابـة

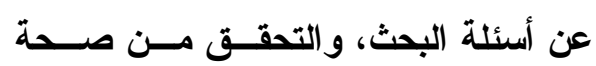
فرضيه:

أولاً: للإجابة عن السؤال الأول، ونصه: ما

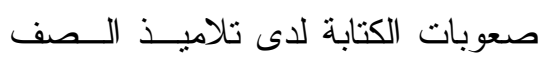
الثانى الابتدائى؟ قام الباحث بـ لـابـ
ووجدوا أن المداخل التى تتتوع فيهـــا

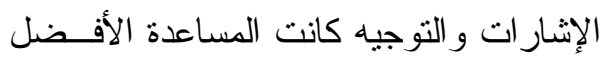
فى جعل عمليــة تــشكيل الحــروف آليــة، وتوصلو ا من خلال هذه التحليلات إلى خمسة مداخل: 1 - مدخل المحاكاة والتقليد الحركى:

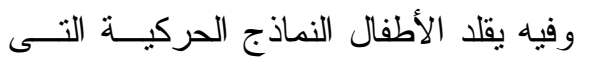

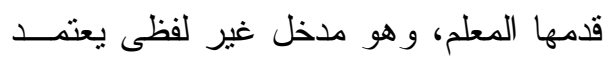
على الإشار ات كدلائل نوجه الأطفال r - مدخل الداتل البصرية: ويتضمن التزويد بعدد مــن الأســهم لإنه

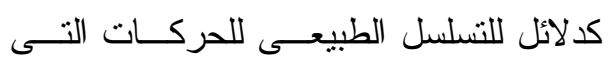

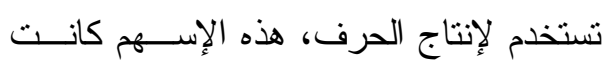

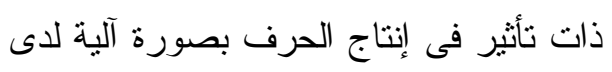
الأطفال الذين يعانون من مشكلات الكتابـــة

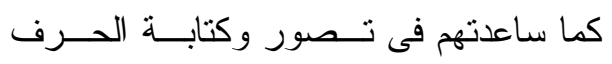
بصورة صحيحة من الذاكرة. r- ـ مدخل الاسترجاع من الذاكرة:

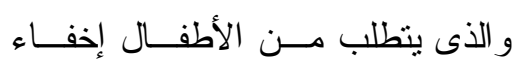
الحروف وكتابتها من الذاكرة، ويشكل العمل بلن الاطل

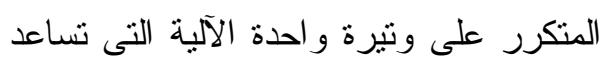

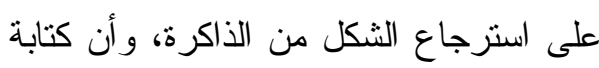

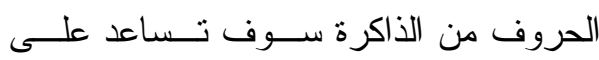

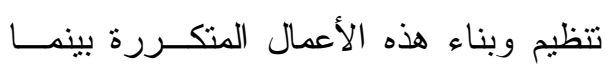
التعليم التقليدى يعتمد على نسخ الحروف من لتهن

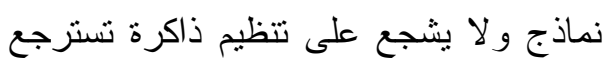
الصيغ المنكررة. 


$$
\begin{aligned}
& \text { منها، ثم إعادة النظر فيها وتعديلها فى } \\
& \text { - إعداد قائمة بصعوبات الكتابة لدى تلاميذ }
\end{aligned}
$$

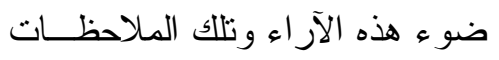

$$
\begin{aligned}
& \text { و إعداد الصورة النهائية لها. }
\end{aligned}
$$

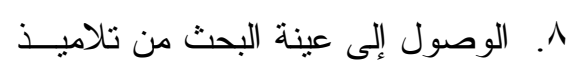

$$
\begin{aligned}
& \text { الصف الثانى الابتدائى. }
\end{aligned}
$$

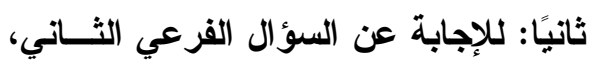

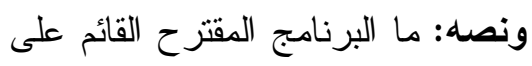

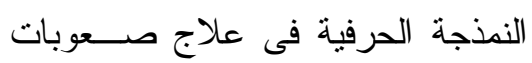

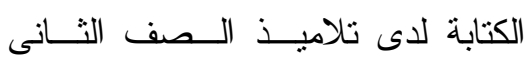

$$
\begin{aligned}
& \text { الابتدائى؟ قام الباحث بما يلي: }
\end{aligned}
$$

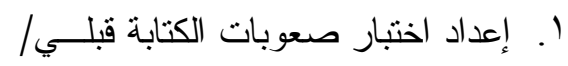

$$
\begin{aligned}
& \text { بعدي، مرفق به مقياس تقدير لتصحيح }
\end{aligned}
$$

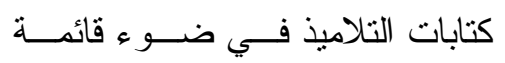

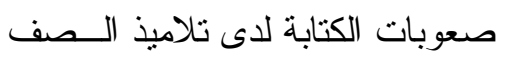

$$
\begin{aligned}
& \text { الثانى بالمرحلة الابتدائية. }
\end{aligned}
$$

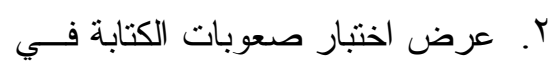

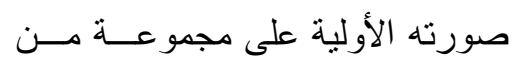

$$
\begin{aligned}
& \text { السادة المحكمين. } \\
& \text { r. تعديل اختبار صعوبات الكتابـــة فـــي } \\
& \text { ضو ء آر اء السادة المحكمين. }
\end{aligned}
$$

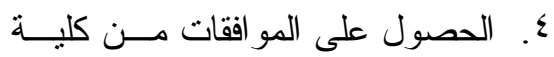

$$
\begin{aligned}
& \text { التربية بالمنصورة ومديرية التربيــة }
\end{aligned}
$$

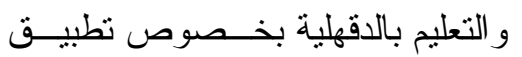

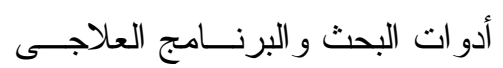

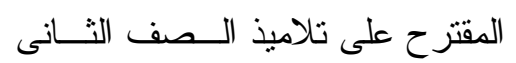

$$
\begin{aligned}
& \text { بالمرحلة الابتدائية. }
\end{aligned}
$$

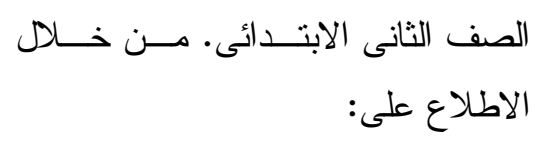

$$
\begin{aligned}
& \text { ا ـ الأدبيات و الدر اســات الـــابقة التــي } \\
& \text { تتعلق بصعوبات التعلم بصفة عامــة }
\end{aligned}
$$

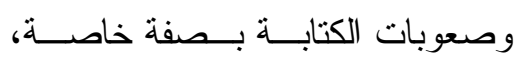

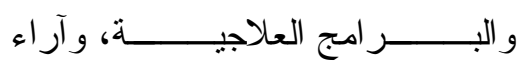

$$
\begin{aligned}
& \text { المتخصصين، و الخبر اء فى الدر اسات }
\end{aligned}
$$

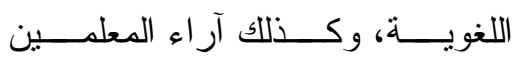

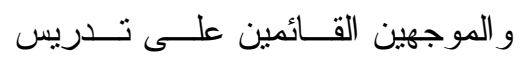

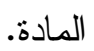

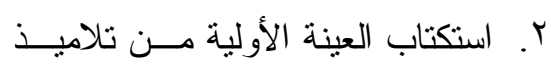

$$
\begin{aligned}
& \text { الصف الثانى الابتدائي. } \\
& \text { r. تحليل الكتابات اليدوية غير الواضحة الابتئ } \\
& \text { لعينة التلاميذ الأولية. } \\
& \text { ع. تطبيق اختبار الذكاء المصور (إعداد / لإدهاء } \\
& \text { أحمد ذكي صالح). } \\
& \text { ๑. تطبيق مقياس نقدير سلوك التلميذ لفرز } \\
& \text { حالات صعوبات التعلم. } \\
& \text { 7. إعداد استبانة لتحديد صعوبات الكتابة } \\
& \text { لاى تلاميذ الصف الثانى الابتدائى. }
\end{aligned}
$$

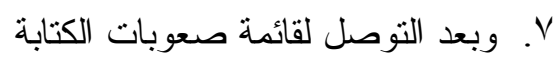

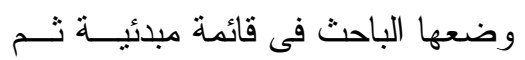

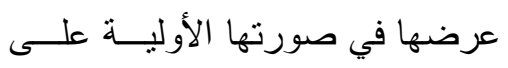

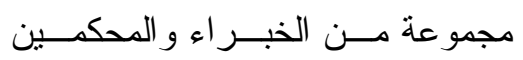

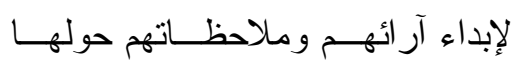

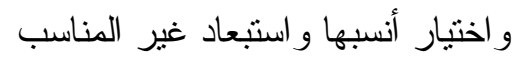


0. تقديم توصيات ومقترحات في ضوء

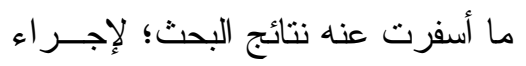

در اسات وبحوث مستقبلية.

• أولاً: النتائج المتعلقة بالإجابة عن السؤال

الأول،ونصه: ما صــوبات الكتابــة

اليدوية لاى تلاميذ الــصف الثـاني

الابتدائي؟ تمت إجابة هذا السؤال من

خلال الإجر اءات التالية:

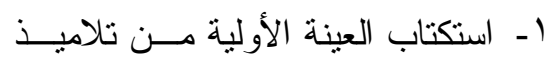

الصف الثانى الابتدائي.

r- تحليل الكتابات اليدوية غير الواضحة

لعينة التلاميذ الأولية.

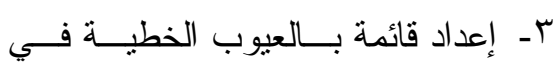

كتابات تلاميذ الصف الثانى الابتدائي.

ع- تطبيق اختبار الذكاء المصور ( إعداد/

$$
\text { أحمد زكي صالح ). }
$$

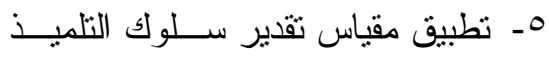

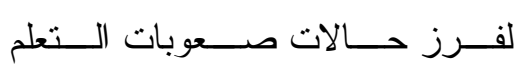

PBRSIM

• ثانيًا: النتائج المتعلقــة بالإجابــة عــن

السؤال الثاني، الــــي نــصه: مــــا

البرنامج العلاجي المقترح القائم على

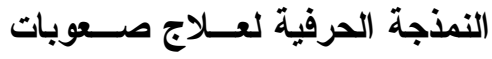

الكتابة لاى تلاميذ المرحلة الابتدائية؟

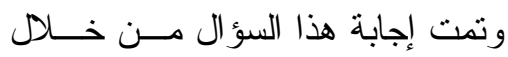

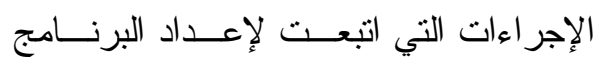

ه. تطبيق اختبار صعوبات الكتابة قبليــاً

$$
\text { على أفر اد العينة. }
$$

7. تفريغ البيانات، وترتيــب صــعوبات

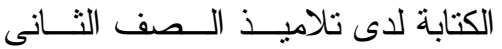

بالمرحلة الابتدائية في ضوء منوسـط ليط

$$
\text { الوزن النسبي. }
$$

V بناء البرنامج العلاجي المقتــرح مسن

حيث |(تحديد الفلسفة المبني عليهـا

و أهدافه العامة و الخاصة و الإجر ائيــة

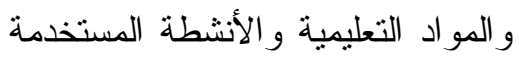

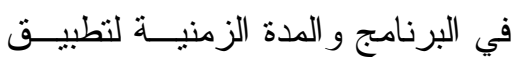

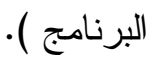

ثُاثثاً: للإجابة عن السؤال الثالث، ونصه: ما

فعالية البرنامج المقترح القائم علــى

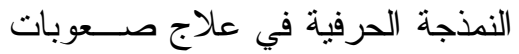

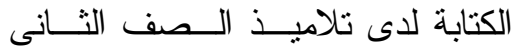

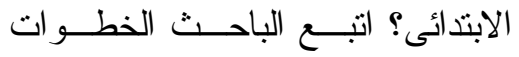

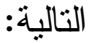

1. تطبيق البرنامج العلاجى المقترح على

عينة البحث (المجمو عة التجريبية).

r. تطبيق اختبار صعوبات الكتابة بعديًا

على عينة البحث.

r. معالجة البيانات إحصائيًا.

ء. تفسير النتائج في ضوء نتائج النطبيق

القبلي و البعدي. 


$$
\begin{aligned}
& \text { المقترح على تلاميذ الصف الثـاني } \\
& \text { الابتدائي، ونصه: }
\end{aligned}
$$

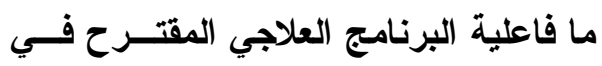

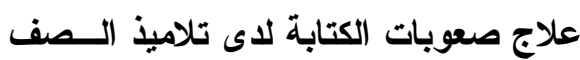

$$
\begin{aligned}
& \text { الثاني الابتدائي. }
\end{aligned}
$$

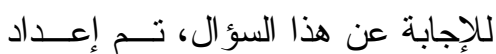

$$
\begin{aligned}
& \text { اختبار صعوبات الكتابة لدى تلاميذ المرحلة } \\
& \text { الابتدائية؛ للتحقق من صحة الفروض. }
\end{aligned}
$$

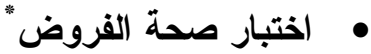

$$
\begin{aligned}
& \text { • اختبار صحة الفرض الأول: } \\
& \text { " بوجد فروق ذات دلالة إحصائية عند } \\
& \text { مستوى دلالة( 0., · ) بين منوسط درجات }
\end{aligned}
$$

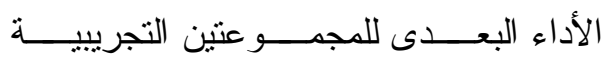

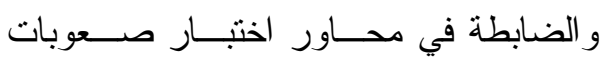

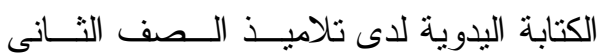

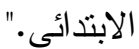

$$
\begin{aligned}
& \text { و لاختبار صحة هذا الفرض تم وصف } \\
& \text { وتلخيص بيانات البحث بحساب (المتوســ }
\end{aligned}
$$

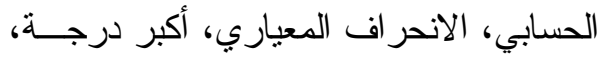

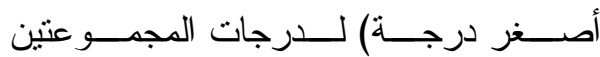

$$
\begin{aligned}
& \text { التجريبية و الضابطة في التطبيــق البعـدي درجي }
\end{aligned}
$$

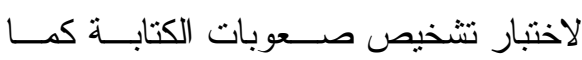

$$
\begin{aligned}
& \text { يوضحها الجدول التالي: }
\end{aligned}
$$

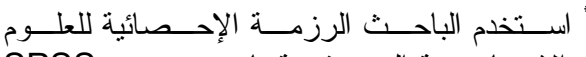

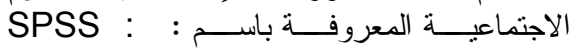

$$
\begin{aligned}
& \text { Statistical Package for the Social } \\
& \text { IA الاصدار Sciences } \\
& \text { العلاجي المقترح. } \\
& \text { البرنامج العلاجي المقتر ح. } \\
& \text { في البرنامج المقترح المقترح. } \\
& \text { العلاجي المقتر ح. } \\
& \text { على المحكمين. }
\end{aligned}
$$


جدول(r) الإحصاءات الوصفية لارجات المجموعتين في التطبيق البعدي لاختبار تثخيص صعوبات الكتابة .

\begin{tabular}{|c|c|c|c|c|c|c|c|}
\hline المتوسطين & درجة & أصغز & المعياري & الحسابي & العدد & الججموعة & الصعوبة \\
\hline \multirow{2}{*}{.69} & $\varepsilon$ & 1 & $1.1 \%$ & r.l $\leq$ & $\leq r$ & تجريبية & \multirow{2}{*}{ الصعوبة ا } \\
\hline & r & . & $\cdot . \leqslant V$ & $1, r 1$ & $\varepsilon r$ & ضابطة & \\
\hline \multirow{2}{*}{$1.7 \mathrm{~V}$} & $\varepsilon$ & 1 & $1, r$. & $r, \leqslant r$ & $\varepsilon r$ & تجريبية & \multirow{2}{*}{ الصعوبة r } \\
\hline & 1 & . & 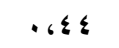 & $\cdot . V \leqslant$ & s & ضابطة & \\
\hline \multirow{2}{*}{ rGYT } & $\varepsilon$ & . & 1,40 & r.OA & $\leq r$ & تجريبية & \multirow{2}{*}{ الصعوبةr } \\
\hline & r & . & . $0 Y$ & rra & s & ضابطة & \\
\hline \multirow{2}{*}{$1 ، \leqslant V$} & $\varepsilon$ & . & $1, r 1$ & r.rT & $\varepsilon r$ & تجريبية & \multirow{2}{*}{ الصعوبة ؛ } \\
\hline & r & . & .69 & • • ^ & $\leq r$ & ضابطة & \\
\hline \multirow{2}{*}{ r.rT } & $\varepsilon$ & · & $1,1 \leq$ & r.07 & $\leq r$ & تجريبية & \multirow{2}{*}{ الصعوبةه } \\
\hline & r & . & $.0 \mathrm{VV}$ & r r & $\leq r$ & ضابطة & \\
\hline \multirow{2}{*}{. rv. } & $\varepsilon$ & $r$ & $.6 V Y$ & r.rV & $\leq r$ & تجريبية & \multirow{2}{*}{ الصعوبة> } \\
\hline & r & . & . $\mathrm{V} 0$ & $1.7 \mathrm{~V}$ & $\leq r$ & ضابطة & \\
\hline \multirow{2}{*}{ r... } & $\varepsilon$ & . & 16.0 & r.OA & $\leq r$ & تجريبية & \multirow{2}{*}{ الصعوبة V } \\
\hline & $r$ & . & $\cdot \triangleleft \wedge \wedge$ & . . O & $\varepsilon r$ & ضابطة & \\
\hline \multirow{2}{*}{1611} & $\varepsilon$ & · & $1, \leqslant r$ & $r .01$ & $\leq r$ & تجريبية & \multirow{2}{*}{ الصعوبةم } \\
\hline & 1 & . & . $6 \leqslant r$ & $\cdot$. VV & $\{r$ & ضابطة & \\
\hline \multirow{2}{*}{ r.tr } & $\varepsilon$ & . & I.rY & $r(\Lambda)$ & $\leq r$ & تجرييية & \multirow{2}{*}{ الصعوبة9 } \\
\hline & 1 & . & (49 & .619 & $\leqslant r$ & ضابطة & \\
\hline \multirow[t]{2}{*}{$\cdot, \vee \vee$} & $\varepsilon$ & $\cdot$ & $1,1 \mathrm{r}$ & r.lr & $\varepsilon r$ & تجريبية & \multirow{2}{*}{ الصعوية ـ 1} \\
\hline & r & . & . ‘А & $1,4 r$ & $\varepsilon r$ & ضابطة & \\
\hline \multirow{2}{*}{$1 ، \leqslant V$} & $\varepsilon$ & 1 & $1,1 \mathrm{r}$ & r، $\_.$ & $\leq r$ & تجريبية & \multirow{2}{*}{ الصعوبة || } \\
\hline & r & . & .00 & .69 & $\{r$ & ضابطة & \\
\hline \multirow{2}{*}{ r,rt } & $\varepsilon$ & . & 1.17 & r.OT & \& & تجريبية & \multirow{2}{*}{ الصعوبة r | } \\
\hline & 1 & . & . & .rA & $\varepsilon r$ & ضابطة & \\
\hline \multirow{2}{*}{ r.,rT } & $r q$ & r & \&, & rq، & $\varepsilon r$ & تجريبية & \multirow{2}{*}{ صعوبات } \\
\hline & $1 \pi$ & 0 & r.IV & 9.17 & r & ضابطة & \\
\hline
\end{tabular}


جدول(r) المقاييس الإحصائية المستخلصة من شكل الصندوق والنقطة لارجات

\begin{tabular}{|c|c|c|}
\hline \multicolumn{3}{|c|}{ مجموعتي البحث } \\
\hline المجموعة & المجموعة & المقاييس \\
\hline الضابطة & التجرييية & الإحصائية \\
\hline • & ri & أقلّ درجة \\
\hline ir & צ & أكبر درجة \\
\hline $\mathrm{v}$ & rV & الربيع الأدني \\
\hline 9 & rq & الوسبط \\
\hline 11 & $r \varepsilon$ & الربيع الأعلي \\
\hline
\end{tabular}

ويتضح من التمثيل البياني السابق وجود

فروق و اضحة بيانيا بين درجات مجمو عتي لني البحث التجريبية و الــضابطة فــي التطبيــق البعدي لأداة البحث المعبرة عن صــــوبات ولئ الكتابة ككل.

وللتحقق مــن الدلالـــة الإحــصائية

للفرق بين المتوسطين تم اســتخدام اختبـــار ( ت) للمجمو عتين المستقلتين المتساويتين في

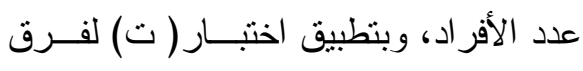
المتوسطين لقياس مقدار دلالة الفــرق بــين منوسطى درجات مجموعتي البحث اتضح ما يلى :
يتضح من الجدول أعلاه أن متوســط

درجات المجموعة التجريبية بالنسبة للاختبار

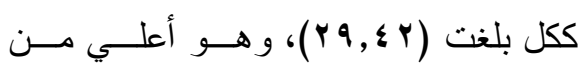

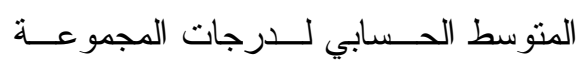

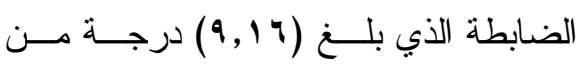

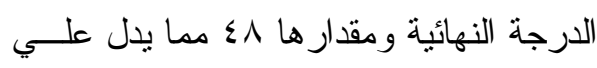
وجود فرق بين منوسطى درجات مجمو عتي

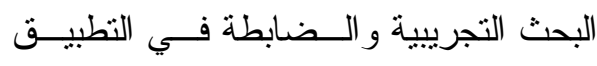
البعدي لاختبار صعوبات الكتابــة لـــــالح المجموعة التجريبية نتيجة تعرضهم للمعالجة

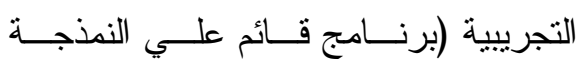
الحرفية). ويمكن عرض نتــائج الــشكل البيــاني

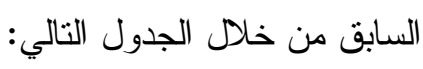




\section{جدول (๕)}

نتائج اختبار " ت " للفرق بين متوسطي درجات المجموعتين في صعوبات الكتابة

\begin{tabular}{|c|c|c|c|c|c|c|}
\hline مستوي & الحربة & قيمة & الالمعراف افي & الحستوسطي & المجموعة & الصعوبة \\
\hline \multirow{2}{*}{ مستوي . م. } & \multirow{2}{*}{$\Lambda \leq$} & \multirow{2}{*}{06.99} & 1.14 & $\left.r_{6}\right) \leq$ & تجريبية & \multirow{2}{*}{ الصعوبة ا } \\
\hline & & & $\cdot 6 \leqslant V$ & $1, Y 1$ & ضابطة & \\
\hline \multirow{2}{*}{ 1 مستوي . م } & \multirow{2}{*}{$\Lambda \leq$} & \multirow{2}{*}{$\Lambda_{6} \cdot r \leq$} & 1.5. & $r, \varepsilon r$ & تجريبية & \multirow{2}{*}{ الصعوبة } \\
\hline & & & . $6 \leqslant \leqslant$ & $.6 V \varepsilon$ & ضابطة & \\
\hline \multirow{2}{*}{ مستوي . م. } & \multirow{2}{*}{$\wedge \leq$} & \multirow{2}{*}{ ס D I I } & סע, & $r, \diamond \Lambda$ & تجريبية & \multirow{2}{*}{ الصعوبة r } \\
\hline & & & $.60 Y$ & سז، . & ضابطة & \\
\hline \multirow{2}{*}{ مستوي } & \multirow{2}{*}{$\Lambda \leq$} & \multirow{2}{*}{$V \cdot r \cdot q$} & $1, Y 1$ & TrTH & تجريبية & \multirow{2}{*}{ الصعوبة ؛ } \\
\hline & & & .607 & . ‘А & ضابطة & \\
\hline \multirow{2}{*}{ مستوي } & \multirow{2}{*}{$\Lambda \varepsilon$} & \multirow{2}{*}{$11,0 . r$} & $1,1 \leqslant$ & Y.0Y & تجريبية & \multirow{2}{*}{ الصعويةه } \\
\hline & & & $.60 \mathrm{~V}$ & سrr & ضابطة & \\
\hline \multirow{2}{*}{ مستوي } & \multirow{2}{*}{$\Lambda \varepsilon$} & \multirow{2}{*}{ \&.797 } & $.6 V r$ & r,TV & تجريبية & \multirow{2}{*}{ الصعوبة 7} \\
\hline & & & . ‘Vo & $1.7 \mathrm{~V}$ & ضابطة & \\
\hline \multirow{2}{*}{ مستوي } & \multirow{2}{*}{$\Lambda \leq$} & \multirow{2}{*}{ 9.VV० } & 16.0 & $r_{6} \diamond \wedge$ & تجريبية & \multirow{2}{*}{ V الصعوبة } \\
\hline & & & $.6 \wedge \wedge$ & . .OH & ضابطة & \\
\hline \multirow{2}{*}{ مستوي } & \multirow{2}{*}{$\Lambda \leq$} & \multirow{2}{*}{$A_{6} \cdot M_{1}$} & $1, \leqslant r$ & $r, \diamond \wedge$ & تجريبية & \multirow{2}{*}{ الصعوبةة } \\
\hline & & & $.6 \leqslant r$ & $.6 V V$ & ضابطة & \\
\hline مستوي & 14 & 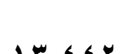 & I.rY & Y،八I & تجريبية & 4 \\
\hline$\cdot 61$ & 10 & 19.6. & . . & .619 & ضابطة & السضمو \\
\hline مستوي & & & 1.14 & r.I & تجريبية & 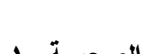 \\
\hline $.6 \cdot 1$ & $\Lambda \varepsilon$ & r.7Y & $.6 \wedge 9$ & I, & ضابطة & \\
\hline مستوي & 14 & $x \times 19$ & $161 \%$ & r ‘ $\varepsilon$. & تجريبية & 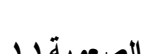 \\
\hline .6 .1 & 的 & v6r 17 & .600 & .694 & ضابطة & الصتوبه ا 1 \\
\hline مستوي & 14 & $\perp 1 \wedge 0$ & 1617 & r.or & تجريبية & $1 \mathrm{I}^{\mathrm{a}}$ \\
\hline$\cdot 6 \cdot 1$ & 16 & 1 & $.6 \leqslant 0$ & $.6 \mathrm{rA}$ & ضابطة & |تصنوبة ا \\
\hline مستوي & $\Lambda \leqslant$ & $r V \Delta=0$ & $\leq, r \leq$ & $r q ، \varepsilon r$ & تجريبية & صعويات \\
\hline$\cdot 61$ & 16 & 1860.0 & r.IV & 9617 & ضابطة & الكتابة \\
\hline
\end{tabular}


'_الإطار النظرى الـــى قــدم الباحــث

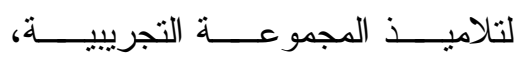

ومايتـــمنه مسـن دروس، وصـــور

$$
\text { توضيحية. }
$$

Y بـبناء البرنامج على النمذجة الحرفيــة،

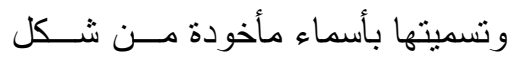

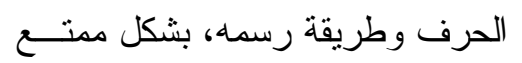

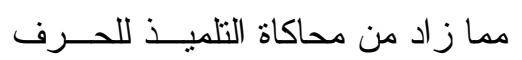

بشكلة الدقيق.

بـ أتاح البرنامج للتناميذ فرصنًا عديــدة

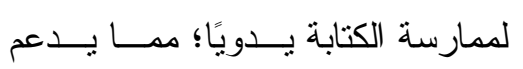

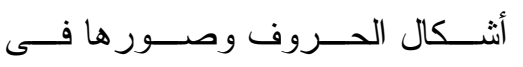

ذاكرتهم، وذلك يساعدهم على إتقـــان

مهارة الكتابة و علاج صعوبتها لــديهم

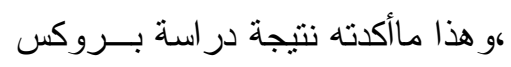

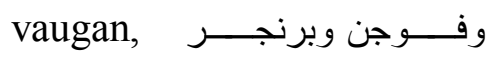

(Brooks berninger, 1999)

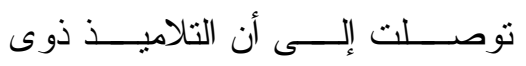

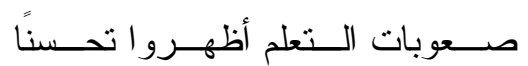

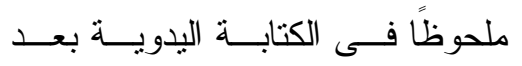

$$
\text { البرنامج العلاجى. }
$$

عـأتاح البرنامج تدريبات علاجية منتو عة

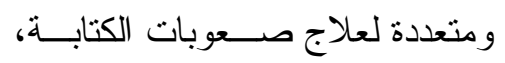

وبطرق مشوقة وجذابة، فجذب انتبــاه

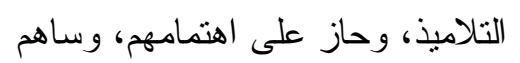

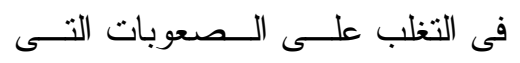

و اجهنه.
يتضح من الجدول السابق أن قيمــة "

ت " المحسوبة بالنسبة لصعوبات الكتابة ككل

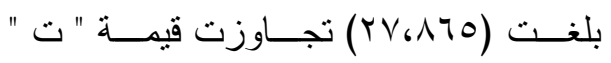

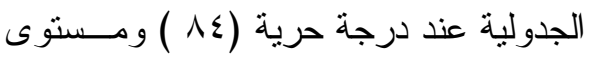

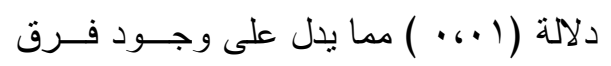

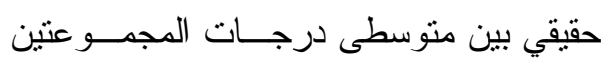

التجريبية و الضابطة فى التطبيــق البعـدي دئي

لصالح المجموعة التجريبية ( ذات المتوسط فيط لإسي

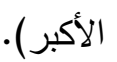

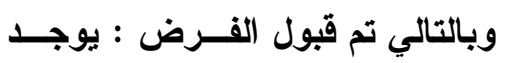

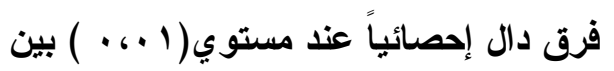

متوسطي درجات طلاب المجموعة الضابطة

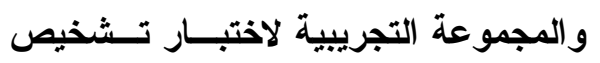

صعوبات الكتابة وذلك لصالح المجموعـة

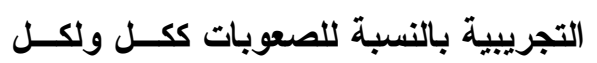

صعوبة فرعية علي حدة.

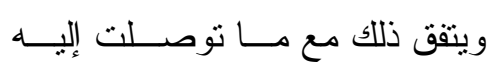

الدر اسات السابقة القائمة على بر امج علاجية

لصعوبات الكتابة، من منل در اسة: صـــلاح

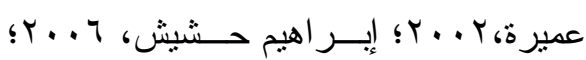

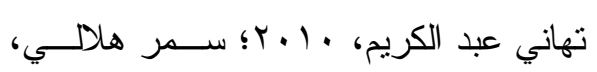

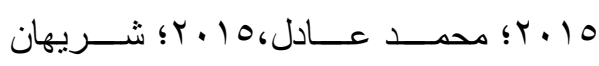

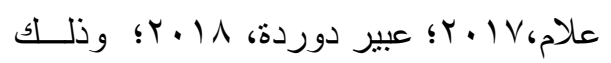

للأسباب التالية:

ويمكن أن ترجع النتيجة إلى: 
يتضح مما سبق: وجود فــروق ذات

ـ_ كثرة التدريبات العلاجية التـى كــان

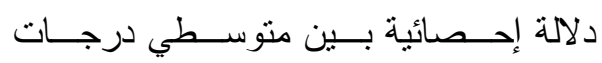

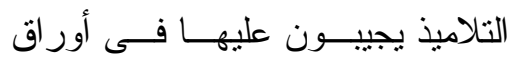

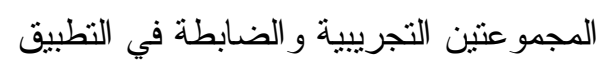

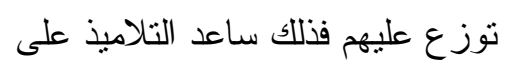

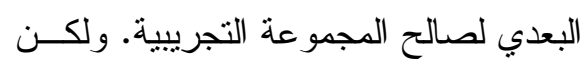

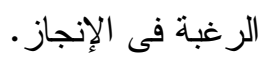

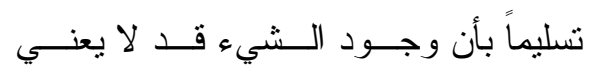

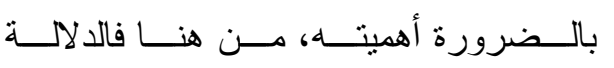

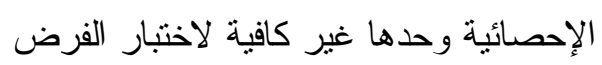

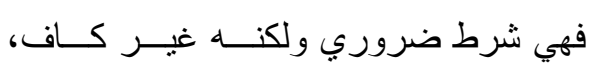
فالضرورة تتحقق بوجود الدلالة الإحــصائية و الكفاية تتحقق بحساب درجة الأثر و أهميــة

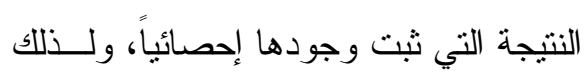
وجب إتباع اختبار ات الدلالـــة الإحــصـائية ببعض الإجر اءات لفهم معنوية النتائج الدالة

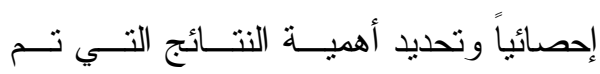
التوصل إليها، ومن هذه الأساليب المناســبة للبحث الحالي اختبار مربع ايتا(n) و واختبار حجم الأثر (d)، ويهدف اختبار مربــع ايتــا ( الى تحديد نسبة من تبــاين المتغيــر

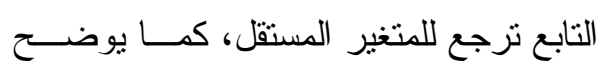

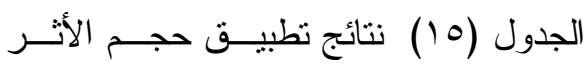

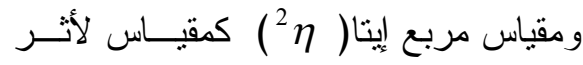

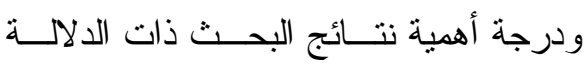
الإحصائية : ودنه اهمجن ؟_أسلوب الثقويم الذى أتبعه الباحث مـــع

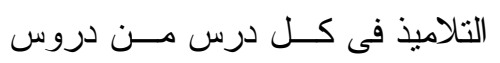

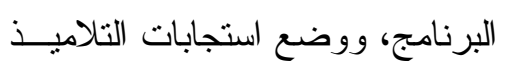
لكل صعوبة فى ملف الإنجاز ، حتـى لئجي يرونها يو ميًا، وليعرفو ا درجة تقدمهم ملئ فى كل صعوبة، وتطبيق كل ماتعلموه

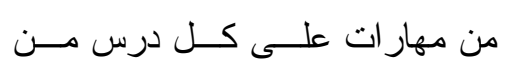
دروس البرنامج المقــرر باســتخدام المهارة التى تم تعليمها منه.

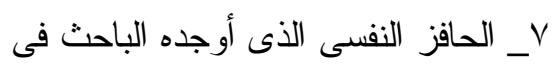

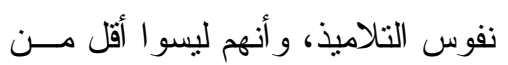
أقر انهم، بل إن درجاتهم فى اختبـــار

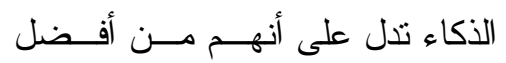
التلاميذ وينبغى أن ينبت للجميع ذلك. * اختبار صحة الفرض الثاني: " يوجد أثر دال إحصائيا للبرنامج الحالي في

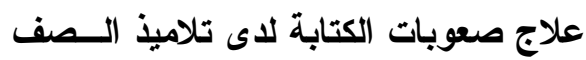
الثاني." 


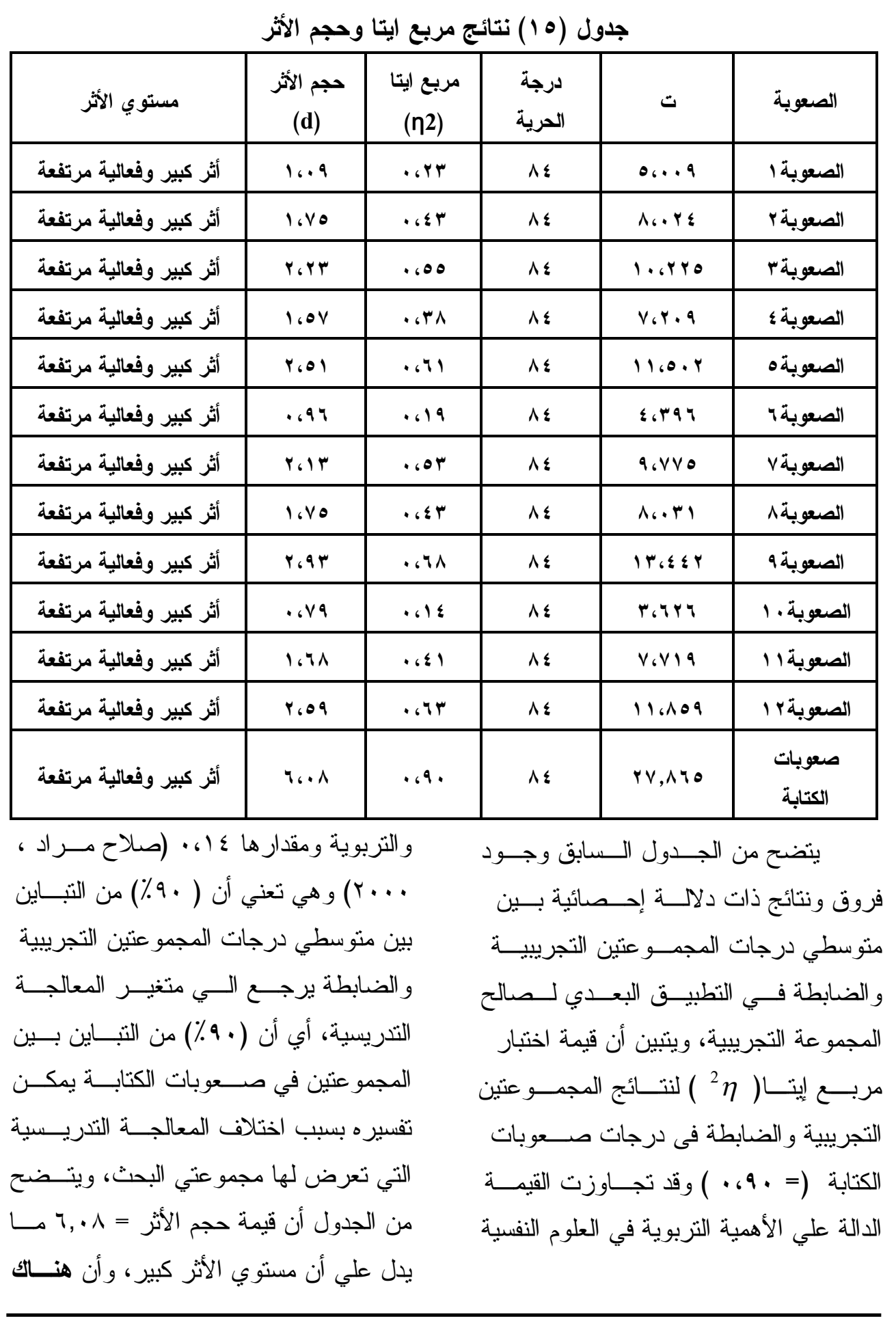


r- عمل دور ات تدرييية لمعلمي ومعلمات اللغة العربية عن كيفية إعــداد أدوات

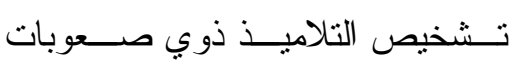
التعلم، وكيفيـــة اكتـشـافهم وتــصميم بر امج علاجية لصعوبات التعلم فــي وكي اللغة العربية.

ثانياً: توصيات خاصة بمعلمي اللغة العربية: 1 - ضرورة الكثف المبكر على التلاميذ الذين بعانون من صعوبات الكتابــة،

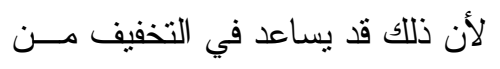

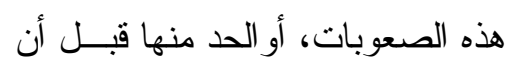
تتفاقم ويصبح من الصعب مو اجنتها. r- الحــرص علــى نتـــوع الأنــشطة

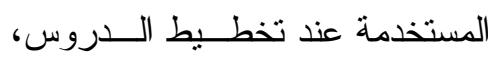
بحيث تكون مناسبة تز اعي الفـــروق الفردية للتلاميذ.

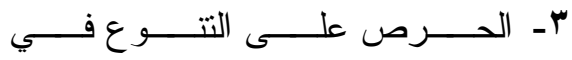
الاستر اتيجيات التذريبية المـستخدمة بشكل يتتاسب مـــع نــوع ع الــصعوبة دئة ودرجتها وخصائص تلاميذها. ثالثًا: توصيات خاصة بالمسئولين عن وضع

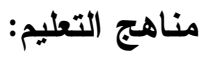
1 - الاهتمام ببناء البر امج التعليمية بنــاء

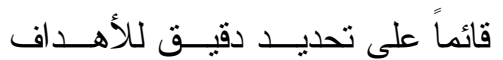
و الوسائل و اســنز اتيجيات التــــيس وأساليب التقويم التى تعتمد على تتوع الأنشطة.
فاعلية وأثر كبير ومهم تربويــا لاســتخدام برنامج قائم علي النمذجة الحرفية في علاج صعوبات الكتابة .

ويرجع الباحث نتائج البحــث إلـــ فعاليــة

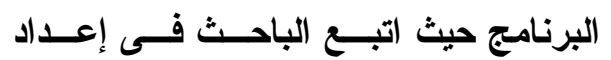
البرنامج مايلى: - تتويع الأنشطة و التنريبات و الممارسات

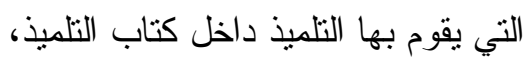
وعرضها بطريقة مشوقة وجاذبة للتلميذ. - وزع الباحث دليل المعلم على المعلمين

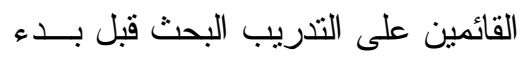

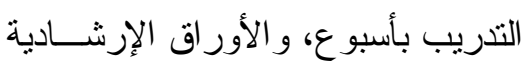
الخاصة بكل درس. - متابعة التلاميذ في أثناء تتفيــذ النــشاط وتقديم الدعم المستمر لهم. توصيات البحث : أولًا: توصيات خاصـــة بالمـسئولين عــن المعلمين فى أثناء الخدمة :

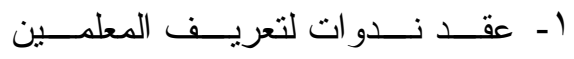
بخصائص التلاميــذذ ذوي صــــوبات التعلم عامة وصعوبات الكتابة خاصة. r- إعداد برنامج تدريبي لتدريب المعلمين

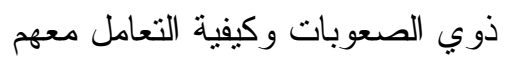
وعلاج هـــه الـصعوبات وخاصـــة

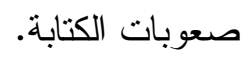




\begin{tabular}{|c|c|}
\hline خامساً : توصيات خاصة بأوليائ الأمور : & r- الأخذ بالاتجاه التكاملي فـــ تــدريس \\
\hline 1 - ضرورة التعرف على الصعوبات التي & فــروع اللغـــة العربيــة، و الاهتــــام \\
\hline يعاني منها الأبناء وخاصة صـــعوبات & 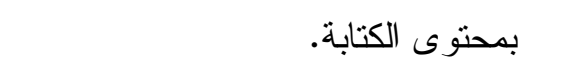 \\
\hline 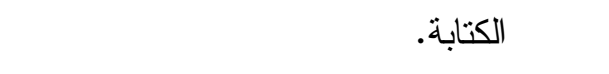 & r- توفير الإمكانات الــضرورية لــسير \\
\hline r- مساعدة أولياء الأمــور الأبنـــاء فــي & 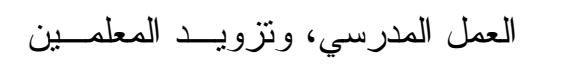 \\
\hline التغلب على صعوبات الكتابة، وزيادة & بدليل يرشدهم إلى الطر ائق و الوسائل \\
\hline دافعيتهم اللتعلم. & و الأنشطة المنو عة التى يمكـن فــى \\
\hline مقترحات البحث : & ضوئها ابتكار الجديد لتحقيق الأهداف \\
\hline بستــشرف البحــــث الحـــالي رؤيــــة & وتتمية المهار ات \\
\hline مستقبلية لعدد من الموضوعات البحثية التـى & ــــ العناية بمحتوى كتاب القــــر اءة الــذي \\
\hline يمكن أن تكون امتداداً لها أو طرقاً لأبـــواب & يمكن التلميذ من القراءة بسهولة مسـن \\
\hline جديدة فى مجال هذه الدر اسة، وذلــــ فــى & خلال وضع التشكيل على كل حرف، \\
\hline الأفكار البحثية التالية: & و الاهتمام بالتزتيب و التدرج المناســب \\
\hline 1 - ـ در اسة تتخيصية علاجيــة لــصعوبة & في تعلم القر اءة بحيث يبدأ بــالحروف \\
\hline الإنتبير الكتابي لدى صفوف المرحلـــة & 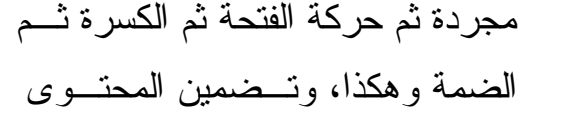 \\
\hline H. & نماذج كتابية عديدة . \\
\hline r - إعداد برنامج تدريبي قائم على نــشاط & هـ الاهتمام بكر اســـة الخــــوتزويــدها \\
\hline القصة؛ لتحسين الأداء الكتابي. & بنماذج شارحة للمعلم وللتلميذ، ونتويع \\
\hline كا - فاعلية برنامج قــائم علــى الألعـــاب & النماذج المعروضه بحيث تكون جاذبة \\
\hline التعليمية، لعلاج صعوبات الكتابة لدى & ومشوقة للتناميذ. \\
\hline تلاميذ المر احل الابتدائية. & آ- العناية بــصعوبات الــتـعلم وخاصــة \\
\hline 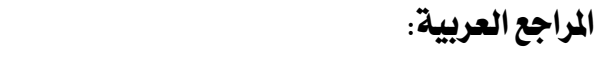 & صعوبات الكتابة وتقديم طرق عــلاج \\
\hline ( ) إبر اهيــــــم محمـــــود طلـب حـشيش & هذه الصعوبات وتضمينها فـــي دليــلـ \\
\hline 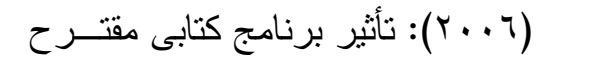 & \\
\hline فى علاج رداءة الخطوط لـــدى تلاميـــذ & \\
\hline الصف الر ابع بالمرحلة الابتدائية، رسالة & \\
\hline
\end{tabular}


و التزبويــــة و الاجتماعيـــة، الطبعــــة الأولي، الأنجلو المصرية، القاهرة.

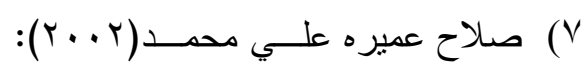

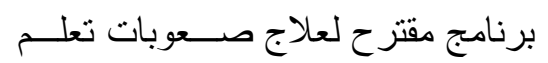

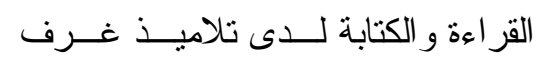
المصادر بالمدرسة الابتدائية التأسيسيّة، بدولة الإمارات العربية المتحدة، معهد بالئه

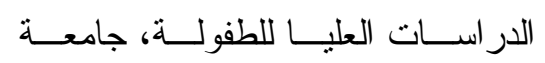
عين شمس.

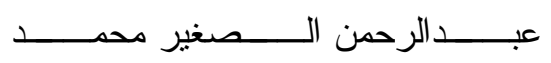

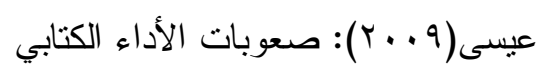
لاى المتعلمين الكبار بـسلطنة عمـــان:

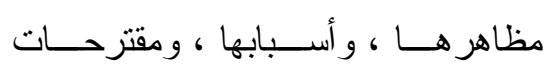
علاجها، بحوث المؤتمرات متاح علــى هـــا الــر ابط: http://search.mandumah.com/R ecord/66950

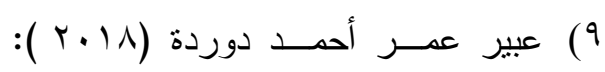
فاعلية برنامج مقترح قائم على الوسائط

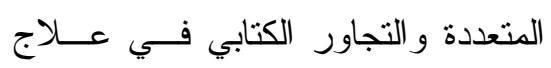

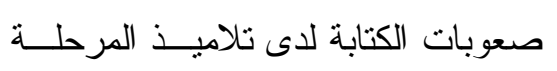
الابتدائية بدولة ليبيا، رســالة دكتــور اه

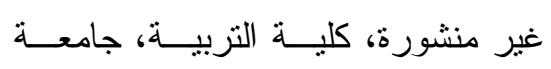
المنصورة.

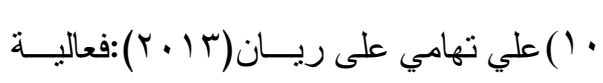

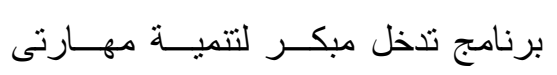

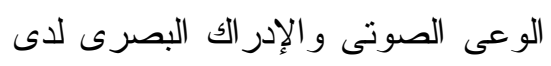

ماجستير غير منشورة، كليـــة التربيــة، جامعة كفر الثيخ. مانئ.

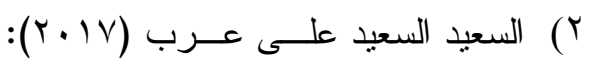
فعالية برنامج متعدد الذكاءات فى علاج

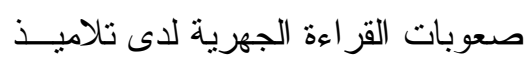

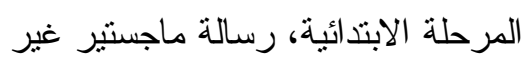

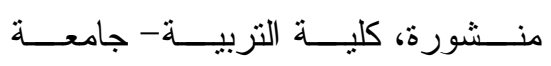

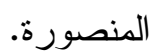

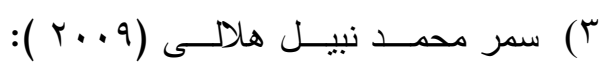

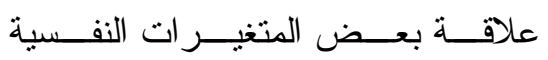

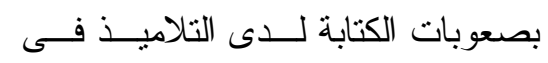

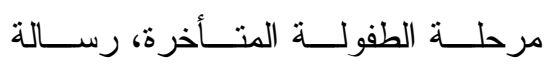
ماجستير غير منشورة، كليــة التزبيـــة جامعة المنصورة.

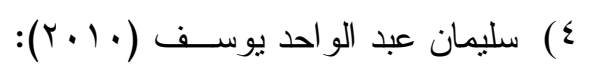
المرجع في صعوبات الــتعلم النمائيــة و الأكاديمية والاجتماعية و الاففعاليـــة. مكتبة الأنجلو المصرية. 0) شريهان محمد فريــد عــلام(Y) (Y): استخدام مدخل الحواس المتعددة لعـلاج

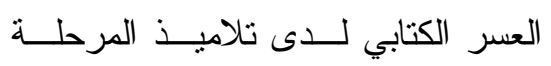

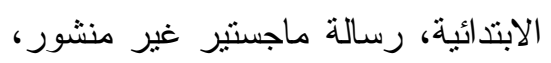
كلية التزبية، جامعة دمياط.

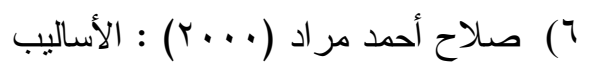
الإحصائية في الاقتصاد المنزلي النفسية 
علاج صعوبات الكتابــة لــدى تلاميــذ

المرحلة الابتدائية. رســالة ماجـستير،

غير منشورة، كليـــة التزبيـــة، جامعـــة

$$
\text { المنصورة. }
$$

14) Silver, A., \& Hagin, R. (2002).

Disorders of learning in childhood ( $2^{\text {nd }}$ ed). New York: Wiley.

15)Smith, F. (2002). Is roles playing an effective EFL teaching technique WATESOL working papers No. 3, U.S. district of Colombia.

16)-William E.Phillips(2012)

.Methods for sight word

Recognition

in

Kindergarten:Traditional

Flashcard Method

Multisensory Approach
الأطفال المعرضين لخطــر صـــوبات

القر اءة و الكتابة، رسالة ماجستير ، غيــر

منشورة، جامعة عين شمس.

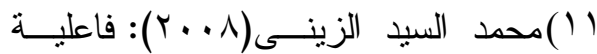

استز اتيجية مقترحة قائمة على نمـــوذج

التتشيط التفاعلى فــى تتمبــة مهـــار ات

القر اعة و الكتابة للمبتدئين. مجلـــة كليــة

التزبية، جامعة المنصورة، عدد خاص،

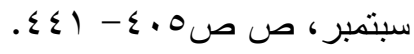

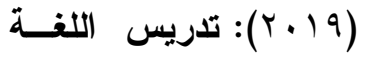
( )

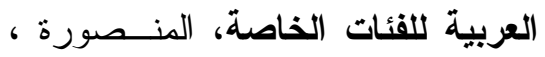
مطبعة المنار .

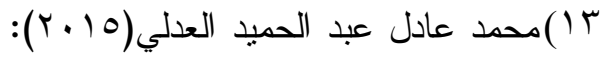

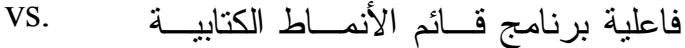

باستخدام المدخل متعدد الحـــواس فــى 